
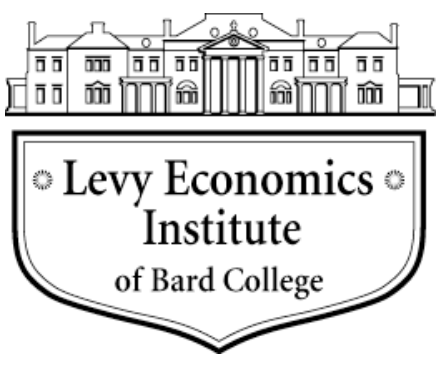

Working Paper No. 734

\title{
The Crisis of Finance-dominated Capitalism in the Euro Area, Deficiencies in the Economic Policy Architecture, and Deflationary Stagnation Policies*
}

by

\author{
Eckhard Hein \\ Berlin School of Economics and Law \\ and Institute for International Political Economy, Berlin
}

October 2012

\begin{abstract}
* For a more detailed elaboration on the macroeconomic theory of finance-dominated capitalism, see the respective chapters in my book The Macroeconomics of Finance-dominated Capitalism - and Its Crisis (Hein 2012a). The present paper is based on this theory, and it extends and updates the analysis of the euro crisis I have presented in Hein (2012b). I would like to thank Achim Truger for his helpful comments and Matthias Mundt for his valuable research assistance.
\end{abstract}

The Levy Economics Institute Working Paper Collection presents research in progress by Levy Institute scholars and conference participants. The purpose of the series is to disseminate ideas to and elicit comments from academics and professionals.

Levy Economics Institute of Bard College, founded in 1986, is a nonprofit, nonpartisan, independently funded research organization devoted to public service. Through scholarship and economic research it generates viable, effective public policy responses to important economic problems that profoundly affect the quality of life in the United States and abroad.

\author{
Levy Economics Institute \\ P.O. Box 5000 \\ Annandale-on-Hudson, NY 12504-5000 \\ http://www.levyinstitute.org
}

Copyright (C) Levy Economics Institute 2012 All rights reserved

ISSN 1547-366X 


\begin{abstract}
In this paper the euro crisis is interpreted as the latest episode in the crisis of finance-dominated capitalism. For 11 initial Euro area countries, the major features of finance-dominated capitalism are analyzed; specifically, the increasing inequality of income distribution and the rising imbalances of current accounts. Against this background, the euro crisis and the economic policy reactions of European governments and institutions are examined. It is shown that deflationary stagnation policies have prevailed since 2010, resulting in massive real GDP losses; some improvement in the price competitiveness of the crisis countries but considerable and persistent current account imbalances; reductions in government deficit-to-GDP ratios but continuously rising trends in gross government debt-to-GDP ratios; a risk of further recession for the euro area as a whole - and the increasing threat of the euro's ultimate collapse. Therefore, an alternative macroeconomic policy approach tackling the basic contradictions of finance-dominated capitalism and the deficiencies of European economic policy institutions and strategies - in particular, the lack of (1) an institution convincingly guaranteeing public debt and (2) a stable and sustainable financing mechanism for acceptable current account imbalances-is outlined.
\end{abstract}

Keywords: Finance-dominated Capitalism; Distribution; Financial and Economic Crisis; European Economic Policies

JEL Classifications: E25, E58, E61, E63, E64, E65 


\section{INTRODUCTION}

In this paper we interpret the recent crises which have struck the European Union (EU) and the Euro area as the most recent episode of the crisis of finance-dominated capitalism. Since the early 1980s, the following major characteristics of finance-dominated capitalism have developed, to different degrees in different countries (Hein, 2012a): the de-regulation of national and international goods, labor and financial markets, in particular, the re-distribution of income at the expense of (low) wages, and rising imbalances of current accounts at the global level and at regional levels, in particular within the Euro area since the introduction of the euro in 1999. Starting with the collapse of the subprime mortgage market in the US in 2007, which gained momentum with by the breakdown of Lehmann Brothers in 2008 and which led to the Great Recession at the world scale in 2008/09, the crisis of finance-dominated capitalism could be observed, with the euro-crisis since 2010 as the latest episode. This crisis is threatening the further existence of the euro because of two major deficiencies in the specific architecture of economic policy making in the Euro area. First, the explicit guarantee of public debt of member countries by the monetary authority of the currency union, the European Central Bank (ECB), is excluded from the treaties and regulations of the EU. Therefore, member country governments issue debt in a common currency, the euro, but not in their own currency, in the sense that their own central bank would guarantee the monetisation of this debt if required. Second, stable and sustainable fiscal transfers among member countries have also been ruled out by the treaties, so that government debt of a single member country is not guaranteed by the community of member country governments as a whole. Since there also have been no efficient mechanisms to prevent the building up of external macroeconomic imbalances across the Euro area countries, theses imbalances meant increasing indebtedness of domestic sectors of current account deficit economies denominated in the common currency. In the course of the crisis these two institutional deficiencies became obvious and would have required rapid institutional change. However, this is not what happened, because European economic policy makers, dominated by the key current account surplus economy, Germany, rather narrowly, have interpreted the crisis as a public debt crisis caused by irresponsible governments in the countries initially affected by the crisis. The reaction therefore has been imposing austerity policies on the countries in calamities. This has prolonged the crisis in these countries, threatens to cause another recession

for the Euro area as a whole in 2012/13 and is imposing deflationary stagnation pressures on the Euro area and finally risks the collapse of the euro. 
In what follows we provide an alternative interpretation of the euro-crisis as a specific and systemic crisis of finance-dominated capitalism in the Euro area, and we outline the basics of an alternative economic policy strategy without being able to go into too much detail. In Section 2 we start with an overview over the development of income distribution in the important initial 11 Euro area countries (EU-12, excluding Luxemburg): Austria, Belgium, Finland, France, Germany, Greece, Ireland, Italy, the Netherlands, Portugal, and Spain. We derive a typology of macroeconomic developments before the crisis focussing on two extreme types, the "debt-led consumption boom" type and the "export-led mercantilist" type, and sketch the concomitant current account imbalances in the Euro area as a whole. Section 3 deals with the euro-crisis, its interpretation by the dominant economic policy makers, the misguided policy responses and their results so far. Finally, in Section 4 we finally draft an alternative macroeconomic policy approach aiming at overcoming the deficiencies of the present economic policy architecture and economic policy making in the Euro area. The last section sums up and concludes.

\section{FINANCE-DOMINATED CAPITALISM IN THE EURO AREA: RISING INEQUALITY AND MACROECONOMIC IMBALANCES}

Three main channels through which finance-dominated capitalism may have contributed to redistribution of income at the expense of (low) wage incomes can be identified (Hein, 2011b, 2012a). First, the sectoral composition of the economy may change in favour of the high profit share financial corporations and at the expense of the non-financial corporate sector and the government sector with lower or zero profit shares. Second, overhead costs, in particular top management salaries and interest payments, as well as profit claims imposed on the corporate sector by shareholders may increase. This causes the mark-up on direct unit labor costs in pricing of firms in incompletely competitive markets to rise and the share of (direct) labor income to fall, because the mark-up has to cover overhead costs and profit claims. Third, the bargaining power of workers and trade unions may be weakened, triggered by shareholder value orientation and short-termism of management, increasing relevance of the financial sector with weak trade unions relative to the non-financial and the government sector with stronger trade unions, the threat-effect of liberalisation and globalisation of finance and trade, deregulation of the labor market, and downsizing or abandoning government demand management policies. The 
result is a tendency of the labor income share to fall and a tendency of personal/household inequality of income to rise. As can be seen from Figure 1 and Table 1, this is indeed what can be observed in the countries which form the core of the Euro area. The labor income share showed a tendency to fall in each of the countries from the early 1990s until 2007, the year before the Great Recession. The Gini coefficient before taxes as a measure of inequality of personal or household market income increased for most of the countries for which data are available from the mid-1980s/mid 1990s until the late 2000s, with the Netherlands being the only exception. And the Gini coefficient after taxes as a measure of inequality of disposable income increased in many countries. However, Belgium, France, Greece, Ireland and Spain did not have to face such an increase.

\section{Figure 1}

Labour income share as percentage of GDP at current factor cost, 1991-2012 Source: European Commission (2012a)

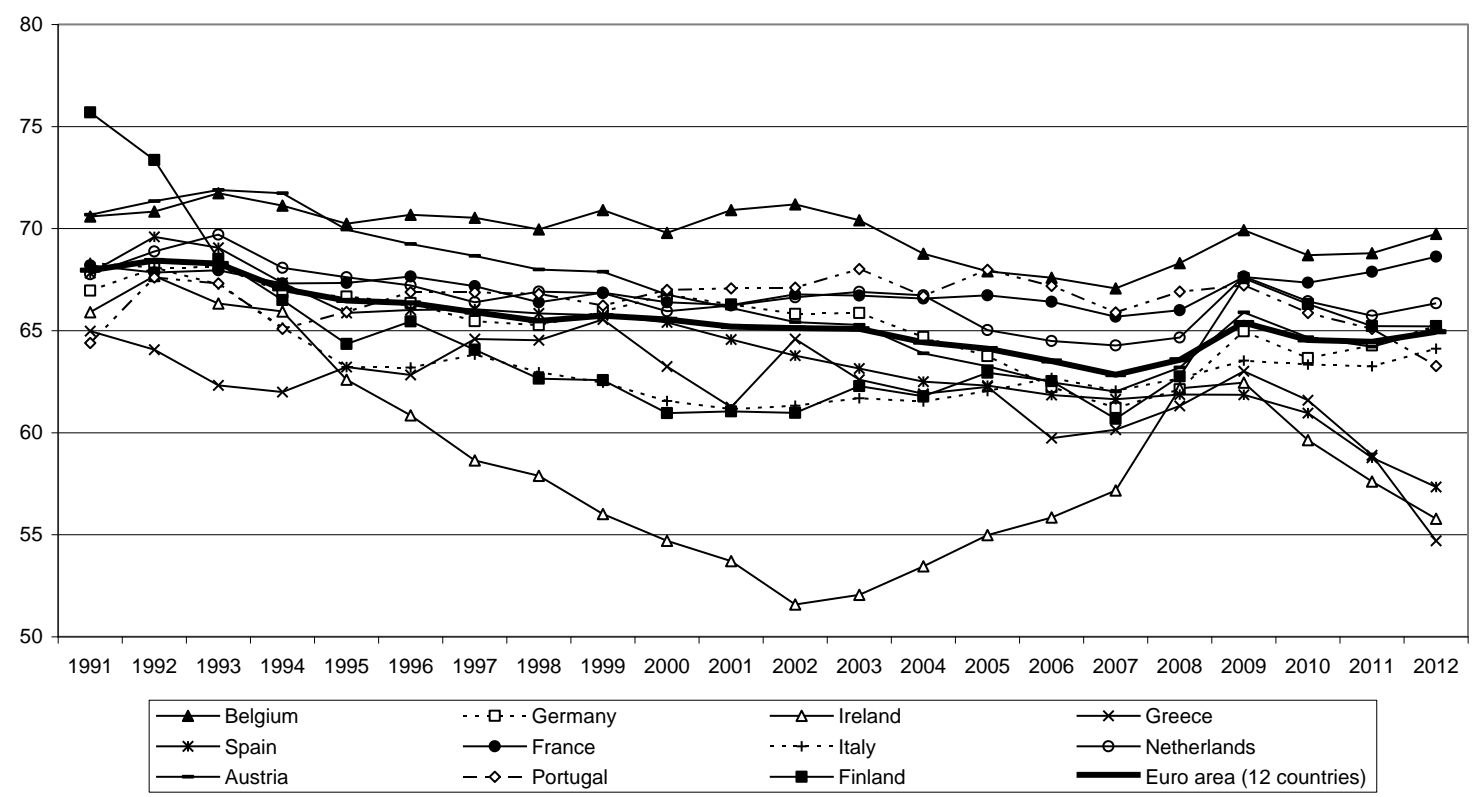

Note: Values for 2012 are European Commission forecasts. 
Table 1

\begin{tabular}{|c|c|c|c|c|c|c|c|}
\hline \multicolumn{8}{|c|}{ Gini coefficient before taxes for households’ market income } \\
\hline Country & $\begin{array}{l}\text { mid- } \\
80 \mathrm{~s}\end{array}$ & $\begin{array}{l}\text { around } \\
1990\end{array}$ & mid-90s & $\begin{array}{l}\text { around } \\
2000\end{array}$ & $\begin{array}{l}\text { mid- } \\
2000 \mathrm{~s}\end{array}$ & $\begin{array}{l}\text { late } \\
2000 \mathrm{~s}\end{array}$ & $\begin{array}{l}\text { Change } \\
\text { from mid- } \\
80 \text { s/around } \\
1990 / \text { mid } \\
90 \text { s } \\
\text { until late } \\
2000 \text { s }\end{array}$ \\
\hline Austria &.. & .. & .. & .. & 0.433 & 0.472 & .. \\
\hline Belgium & 0.449 & .. & 0.472 & 0.464 & 0.494 & 0.469 & 0.020 \\
\hline Finland & 0.387 & .. & 0.479 & 0.478 & 0.483 & 0.465 & 0.078 \\
\hline France & .. & .. & 0.473 & 0.490 & 0.485 & 0.483 & 0.010 \\
\hline Germany & 0.439 & 0.429 & 0.459 & 0.471 & 0.499 & 0.504 & 0.065 \\
\hline Greece & 0.426 &.. & 0.446 & 0.466 & 0.454 & 0.436 & 0.010 \\
\hline Ireland & .. & .. & .. &.. &.. & .. &.. \\
\hline Italy & 0.420 & 0.437 & 0.508 & 0.516 & 0.557 & 0.534 & 0.114 \\
\hline Netherlands & 0.473 & 0.474 & 0.484 & 0.424 & 0.426 & 0.426 & -0.047 \\
\hline Portugal &.. & 0.436 & 0.49 & 0.479 & 0.542 & 0.521 & 0.085 \\
\hline Spain &.. &.. &.. &.. &.. & 0.461 &.. \\
\hline \multicolumn{8}{|c|}{ Gini coefficient after taxes for households' disposable income } \\
\hline Country & $\begin{array}{l}\text { mid- } \\
80 \mathrm{~s}\end{array}$ & $\begin{array}{l}\text { around } \\
1990\end{array}$ & mid-90s & $\begin{array}{l}\text { around } \\
2000\end{array}$ & $\begin{array}{l}\text { mid- } \\
2000 \mathrm{~s}\end{array}$ & $\begin{array}{l}\text { late } \\
2000 \mathrm{~s}\end{array}$ & $\begin{array}{l}\text { Change } \\
\text { mid- } \\
80 \text { s/around } \\
1990 \text { until } \\
\text { late } 2000 \mathrm{~s}\end{array}$ \\
\hline Austria & 0.236 & .. & 0.238 & 0.252 & 0.265 & 0.261 & 0.025 \\
\hline Belgium & 0.274 & .. & 0.287 & 0.289 & 0.271 & 0.259 & -0.015 \\
\hline Finland & 0.209 & .. & 0.218 & 0.247 & 0.254 & 0.259 & 0.050 \\
\hline France & 0.300 & 0.290 & 0.277 & 0.287 & 0.288 & 0.293 & -0.007 \\
\hline Germany & 0.251 & 0.256 & 0.266 & 0.264 & 0.285 & 0.295 & 0.044 \\
\hline Greece & 0.336 &.. & 0.336 & 0.345 & 0.321 & 0.307 & -0.029 \\
\hline Ireland & 0.331 & .. & 0.324 & 0.304 & 0.314 & 0.293 & -0.038 \\
\hline Italy & 0.309 & 0.297 & 0.348 & 0.343 & 0.352 & 0.337 & 0.028 \\
\hline Netherlands & 0.272 & 0.292 & 0.297 & 0.292 & 0.284 & 0.294 & 0.022 \\
\hline Portugal &.. & 0.329 & 0.359 & 0.356 & 0.385 & 0.353 & 0.024 \\
\hline Spain & 0.371 & 0.337 & 0.343 & 0.342 & 0.319 & 0.317 & -0.054 \\
\hline
\end{tabular}

Against the background of rising inequality in personal income distribution in many countries and falling labor income shares in all the countries in our data set in the era of financedominated capitalism or "financialization", different "types of capitalism under financialization" 
have developed in the Euro area, ${ }^{1}$ which are complementary and which have fed rising current account imbalances within the Euro area since its inception, as can be seen in Figure 2.

\section{Figure 2}

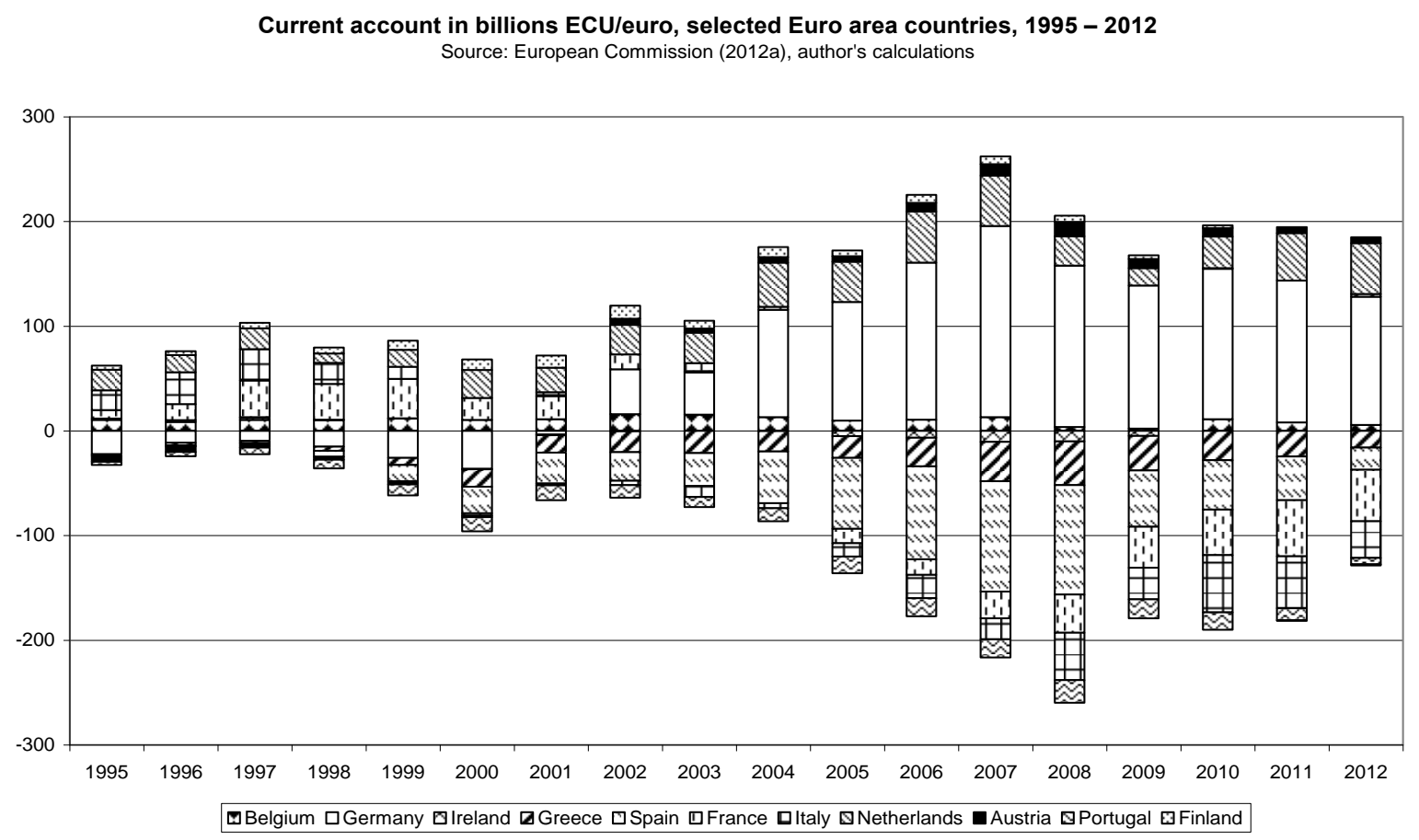

Note: Values for 2012 are European Commission forecasts.

The current account of the Euro area as a whole, as for the initial Euro area (EU-12), has been roughly balanced in the period from 1999 - 2007 (European Commission 2012a), so that in the aggregate current account surplus member countries have their respective deficit counterparts within the Euro area. Of course, individual Euro area member countries also have surpluses or deficits vis-à-vis the non-Euro area rest of the world. But these roughly cancel out for the Euro area in the aggregate.

Distinguishing the types of capitalism under financialization for the Euro area, first, we have the debt-led consumption boom type; second, there has developed a counterpart, the export-led mercantilist type; and third, in between these two extremes we have the domestic demand-led type. In the debt-led consumption boom type it is debt-financed consumption

\footnotetext{
${ }^{1}$ For similar analyses for the global scale see Bibow (2008), Fitoussi/Stiglitz (2009), UNCTAD (2009), van Treeck (2009), Wade (2009), Hein/Truger (2011), Hein (2012a, chapter 6), Stockhammer (2010a, 2010b), and Hein/Mundt (2012).
} 
demand which allows for flourishing aggregate demand and the realisation of rising profits against the background of redistribution at the expense of (low) labor incomes and stagnating real investment, which is another feature of finance-dominated capitalism. ${ }^{2}$ In the export-led mercantilist type it is export surpluses which stabilise aggregate demand and take care of the realisation of profits. ${ }^{3}$ The third type, the domestic demand-led type, can neither rely on export surpluses, which distinguishes it from the second type, nor on flourishing debt-financed consumption, which distinguishes it from the first type. We take average values for the period from 1999 until 2007 to distinguish these types and to allocate the Euro area countries examined in this paper for the period before the Great Recession.

In the period from 1999 until 2007, the debt-led consumption boom type can be found in Greece, Ireland, and Spain (Table 2a). All these economies have seen considerable increases in residential property prices and/or in wealth-income ratios in the period considered here (BIS, 2010; Girouard et al., 2007; Hein, 2012b). This increase in notional wealth, together with liberalised financial markets and weakened conditions of creditworthiness, was conducive to soaring consumption demand and hence considerable growth contributions of private consumption and domestic demand. Relatively high real GDP growth as compared to the export-led mercantilist countries, but negative financial balances (as a share of nominal GDP) of the private household sector and thus increasing private household debt were the consequences. This also translated into negative balances of the private sector as a whole - with the corporate sector being in surplus in all countries of this group except Spain. The public sector contributed to the negative domestic financial balance in Greece, but not in Ireland nor in Spain. Since aggregate domestic expenditures exceeded national income, these countries had to run current account deficits (i.e., the financial balances of the external sectors were positive for each of the countries pursuing the debt-led consumption boom type of development). In particular Greece and Spain had to rely on the inflow of foreign financial resources. Strong domestic demand growth in the debt-led consumption boom countries was accompanied by negative growth contributions of the balance of goods and services in these countries but Ireland, where the

\footnotetext{
${ }^{2}$ On the depressing effects of finance-dominated capitalism, or financialization, on investment in real capital stock, productivity growth and thus potential growth of the economy see Hein (2012, chapters 3 and 4) and the references provided there.

${ }^{3}$ Note that from national accounting we obtain: Gross profits net of taxes $=$ Gross investment + Export surplus + Government budget deficit - Worker's saving + Capitalists' consumption (Kalecki, 1971, p. 82).
} 
growth contribution of external demand was positive, too. ${ }^{4}$ For these countries, above Euro area average unit labor cost growth and inflation accompanied by nominal appreciation of the euro, and thus a loss of competitiveness of domestic producers indicated by positive rates of change in the real effective exchange rate have contributed to the deficits in the balance of goods and services and in the current account. The debt-led consumption boom economies were thus the Euro area demand engines in the period before the Great Recession.

Table 2a

\begin{tabular}{|c|c|c|c|}
\hline \multicolumn{4}{|c|}{$\begin{array}{c}\text { Key macroeconomic variables for "debt-led consumption boom" economies, } \\
\text { average values, } 1999-2007\end{array}$} \\
\hline & Greece & Ireland & Spain \\
\hline $\begin{array}{l}\text { Annual change in labor income share, as percentage of } \\
\text { GDP at current factor costs }\end{array}$ & -0.5 & -0.1 & -0.5 \\
\hline $\begin{array}{l}\text { Financial balances of external sector as a share of nominal } \\
\text { GDP, percent }\end{array}$ & 11.7 & 1.4 & 5.7 \\
\hline $\begin{array}{l}\text { Financial balances of public sector as share of nominal } \\
\text { GDP, percent }\end{array}$ & -5.3 & 1.6 & 0.2 \\
\hline $\begin{array}{l}\text { Financial balance of private sector as a share of nominal } \\
\text { GDP, percent }\end{array}$ & -6.4 & -3.0 & -5.9 \\
\hline $\begin{array}{l}\text { Financial balance of private household sector as a share } \\
\text { of nominal GDP, percent }{ }^{\text {a) }}\end{array}$ & -9.3 & $-6.3^{b)}$ & -1.1 \\
\hline $\begin{array}{l}\text { Financial balance of the corporate sector as a share of } \\
\text { nominal GDP, percent }\end{array}$ & 2.9 & $3.3^{b)}$ & -4.7 \\
\hline Real GDP growth, percent & 4.1 & 6.6 & 3.7 \\
\hline $\begin{array}{l}\text { Growth contribution of domestic demand including stocks, } \\
\text { percentage points }\end{array}$ & 4.8 & 5.3 & 4.8 \\
\hline $\begin{array}{l}\text { Growth contribution of private consumption, percentage } \\
\text { points }\end{array}$ & 2.6 & 2.9 & 2.3 \\
\hline $\begin{array}{l}\text { Growth contribution of public consumption, percentage } \\
\text { points }\end{array}$ & 0.7 & 0.9 & 0.9 \\
\hline $\begin{array}{l}\text { Growth contribution of gross fixed capital formation, } \\
\text { percentage points }\end{array}$ & 1.5 & 1.5 & 1.6 \\
\hline $\begin{array}{l}\text { Growth contribution of the balance of goods and services, } \\
\text { percentage points }\end{array}$ & -0.8 & 1.3 & -1.0 \\
\hline
\end{tabular}

\footnotetext{
${ }^{4}$ In the case of Ireland, the current account deficit (and the positive financial balance of the external sector) was not due to a deficit in external trade but rather a deficit in the flows of primary incomes. Although the balance of goods and services in Ireland was positive, we have not included it into the export-led mercantilist group of countries discussed below, because Ireland, as the other debt-led consumption boom countries, showed a negative balance of the private household sector and the private sector as a whole accompanied by high growth contributions of private consumption. Surpluses in the balance of goods and services were thus required in order to meet the payment commitments associated with the negative balance of primary incomes and to avoid an even larger deficit in the current account, to which the consumption boom and the related deficits of the private household sector contributed considerably.
} 


\begin{tabular}{|l|c|c|c|}
\hline $\begin{array}{l}\text { Net exports of goods and services as a share of nominal } \\
\text { GDP, percent }\end{array}$ & -11.5 & 13.4 & -3.8 \\
\hline & & & \\
\hline Growth rate of nominal unit labor costs, percent & 2.6 & 3.6 & 3.0 \\
\hline Inflation (HCPI growth rate), percent & 3.2 & 3.4 & 3.1 \\
\hline $\begin{array}{l}\text { Growth rate of nominal effective exchange rates (relative } \\
\text { to 35 countries), percent }\end{array}$ & 1.1 & 0.9 & 0.7 \\
\hline $\begin{array}{l}\text { Growth rate of real effective exchange rates (relative to 35 } \\
\text { countries), percent }\end{array}$ & 0.8 & 2.7 & 1.7 \\
\hline \multicolumn{2}{|l|}{} \\
\hline $\begin{array}{l}\text { Note: }{ }^{\text {a) }} \text { adjusted such that private household plus corporate balances sum up to private sector } \\
\text { balance, } \\
\text { Source: European Commission (2012a), author's calculations }\end{array}$ \\
\hline
\end{tabular}

The counterparts to the debt-led consumption boom economies at the Euro area level were the export-led mercantilist economies. This group consists of Austria, Belgium, Finland, Germany, and the Netherlands (Table 2b). These economies were characterised by surpluses in their balances of goods and services and in their current accounts, which means that the financial balances of the respective external sectors were in deficit. Although some of these countries (Belgium, Finland, the Netherlands) had seen considerable increases in wealth-income ratios and/or in residential property prices, whereas others had not (Austria, Germany) (BIS, 2010; Girouard et al., 2007; Hein, 2012b), financial balances of private households remained in surplus, with the exception of Finland. ${ }^{5}$ However, also in Finland, as in the other countries in this cluster, the financial balances of the private sectors were strongly positive. Growth contributions of private consumption and domestic demand were moderate, as for Austria, Finland, Belgium, and the Netherlands, or very weak, as in the case of Germany, and these countries relied considerably on the positive growth contributions of net exports. The basis for external surpluses were thus relatively weak domestic demand, on the one hand, but also low unit labor cost growth and low inflation, on the other hand. For export-led mercantilist countries the real effective exchange rate increased to a lesser extent than in the debt-led consumption boom countries, or even declined as in Austria and Germany, implying an increase in price competitiveness of the former relative to the latter. The export-led mercantilist countries thus benefitted from regional demand being driven by the debt-led consumption boom countries. However, following this model came at a price: GDP growth in the export-led countries

\footnotetext{
5 Finland indeed seems to share some of the characteristics of the debt-led consumption boom type. We have nonetheless included it into the export-led mercantilist group, because of its strong export and current account surpluses.
} 
remained below GDP growth in the debt-led economies, and in particular the more closed large economy of Germany performed even worse than the smaller economies of Austria, Finland, Belgium and the Netherlands.

\section{Table 2b}

\begin{tabular}{|c|c|c|c|c|c|}
\hline \multicolumn{6}{|c|}{$\begin{array}{c}\text { Key macroeconomic variables for "export-led mercantilist" economies, average } \\
\text { values, } 1999-2007\end{array}$} \\
\hline & Austria & Belgium & Finland & Germany & $\begin{array}{l}\text { Nether- } \\
\text { lands }\end{array}$ \\
\hline $\begin{array}{l}\text { Annual change in labor income share, } \\
\text { as percentage of GDP at current factor } \\
\text { costs }\end{array}$ & -0.7 & -0.3 & -0.2 & -0.5 & -0.3 \\
\hline $\begin{array}{l}\text { Financial balances of external sector as } \\
\text { a share of nominal GDP, percent }\end{array}$ & -1.5 & -4.4 & -6.1 & -2.7 & -6.8 \\
\hline $\begin{array}{l}\text { Financial balances of public sector as } \\
\text { share of nominal GDP, percent }\end{array}$ & -1.8 & -0.4 & 3.8 & -2.2 & -0.5 \\
\hline $\begin{array}{l}\text { Financial balance of private sector as a } \\
\text { share of nominal GDP, percent }\end{array}$ & 3.2 & 4.8 & 2.3 & 4.9 & 7.3 \\
\hline $\begin{array}{l}\text { Financial balance of } \\
\text { household sector as a share of } \\
\text { nominal GDP, percent }\end{array}$ & 4.3 & 4.2 & -2.3 & 5.2 & 0.1 \\
\hline $\begin{array}{l}\text { Financial balance of the corporate } \\
\text { sector as a share of nominal GDP, } \\
\text { percent }\end{array}$ & -1.2 & 0.6 & 4.7 & -0.2 & 7.0 \\
\hline Real GDP growth, percent & 2.6 & 2.3 & 3.6 & 1.7 & 2.5 \\
\hline $\begin{array}{l}\text { Growth contribution of domestic } \\
\text { demand including stocks, percentage } \\
\text { points }\end{array}$ & 1.6 & 1.9 & 2.8 & 0.8 & 2.0 \\
\hline $\begin{array}{l}\text { Growth contribution of private } \\
\text { consumption, percentage points }\end{array}$ & 0.9 & 0.8 & 1.7 & 0.5 & 0.8 \\
\hline $\begin{array}{l}\text { Growth contribution of public } \\
\text { consumption, percentage points }\end{array}$ & 0.3 & 0.4 & 0.3 & 0.1 & 0.7 \\
\hline $\begin{array}{l}\text { Growth contribution of gross fixed } \\
\text { capital formation, percentage points }\end{array}$ & 0.3 & 0.6 & 0.7 & 0.2 & 0.4 \\
\hline $\begin{array}{l}\text { Growth contribution of the balance of } \\
\text { goods and services, percentage points }\end{array}$ & 0.8 & 0.4 & 0.7 & 0.9 & 0.5 \\
\hline $\begin{array}{l}\text { Net exports of goods and services as a } \\
\text { share of nominal GDP, percent }\end{array}$ & 3.5 & 4.3 & 7.1 & 3.8 & 6.7 \\
\hline $\begin{array}{l}\text { Growth rate of nominal unit labor } \\
\text { costs, percent }\end{array}$ & 0.5 & 1.6 & 1.1 & -0.1 & 2.2 \\
\hline Inflation (HCPI growth rate), percent ${ }^{a}$ & 1.7 & 2.0 & 1.6 & 1.6 & 2.4 \\
\hline Growth rate of nominal effective & 0.6 & 0.6 & 0.8 & 0.8 & 0.5 \\
\hline
\end{tabular}


exchange rates (relative to 35 countries), percent

Growth rate of real effective exchange rates (relative to 35 countries), percent

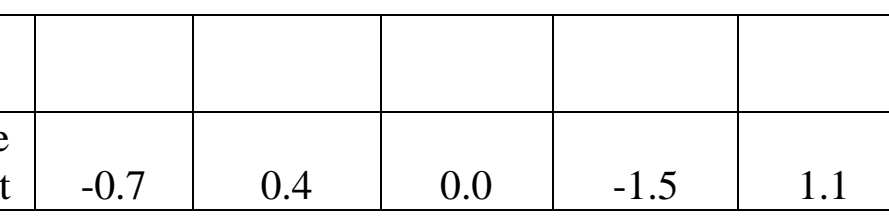

Note: ${ }^{\text {a) }}$ adjusted such that private household plus corporate balances sum up to private sector balance

Source: European Commission (2012a), author's calculations

\section{Table 2c}

\begin{tabular}{|c|c|c|c|c|}
\hline \multicolumn{5}{|c|}{$\begin{array}{l}\text { Key macroeconomic variables for "domestic demand-led" economies, average } \\
\text { values, } 1999-2007\end{array}$} \\
\hline & France & Italy & Portugal & EU-12 \\
\hline $\begin{array}{l}\text { Annual change in labor income share, as } \\
\text { percentage of GDP at current factor costs }\end{array}$ & -0.1 & -0.1 & -0.1 & -0.3 \\
\hline $\begin{array}{l}\text { Financial balances of external sector as a } \\
\text { share of nominal GDP, percent }\end{array}$ & -0.5 & 0.4 & 9.4 & -0.5 \\
\hline $\begin{array}{l}\text { Financial balances of public sector as } \\
\text { share of nominal GDP, percent }\end{array}$ & -2.7 & -2.9 & -4.1 & -1.9 \\
\hline $\begin{array}{l}\text { Financial balance of private sector as a } \\
\text { share of nominal GDP, percent }\end{array}$ & 3.2 & 2.4 & -5.3 & 2.4 \\
\hline $\begin{array}{l}\text { Financial balance of private household } \\
\text { sector as a share of nominal GDP, } \\
\text { percent }^{\text {a) }}\end{array}$ & 3.8 & 3.8 & 0.4 & $\ldots$ \\
\hline $\begin{array}{l}\text { Financial balance of the corporate sector } \\
\text { as a share of nominal GDP, percent }\end{array}$ & -0.7 & -1.2 & -5.6 & $\ldots$ \\
\hline Real GDP growth, percent & 2.2 & 1.5 & 1.8 & 2.2 \\
\hline $\begin{array}{l}\text { Growth contribution of domestic demand } \\
\text { including stocks, percentage points }\end{array}$ & 2.5 & 1.7 & 1.9 & 2.1 \\
\hline $\begin{array}{l}\text { Growth contribution of private } \\
\text { consumption, percentage points }\end{array}$ & 1.4 & 0.7 & 1.4 & 1.1 \\
\hline $\begin{array}{l}\text { Growth contribution of public } \\
\text { consumption, percentage points }\end{array}$ & 0.4 & 0.4 & 0.4 & 0.4 \\
\hline $\begin{array}{l}\text { Growth contribution of gross fixed } \\
\text { capital formation, percentage points }\end{array}$ & 0.7 & 0.5 & 0.0 & 0.6 \\
\hline $\begin{array}{l}\text { Growth contribution of the balance of } \\
\text { goods and services, percentage points }\end{array}$ & -0.3 & -0.1 & -0.1 & 0.1 \\
\hline $\begin{array}{l}\text { Net exports of goods and services as a } \\
\text { share of nominal GDP, percent }\end{array}$ & 0.4 & 0.6 & -9.0 & 1.6 \\
\hline $\begin{array}{l}\text { Growth rate of nominal unit labor costs, } \\
\text { percent }\end{array}$ & 1.8 & 2.3 & 2.7 & 1.5 \\
\hline Inflation (HCPI growth rate), percent & 1.8 & 2.3 & 2.9 & 2.1 \\
\hline Growth rate of nominal effective & 0.7 & 0.9 & 0.4 & $1.5^{b)}$ \\
\hline
\end{tabular}




\begin{tabular}{|l|c|c|c|c|}
\hline $\begin{array}{l}\text { exchange rates (relative to 35 countries), } \\
\text { percent }\end{array}$ & & & & \\
\hline $\begin{array}{l}\text { Growth rate of real effective exchange } \\
\text { rates (relative to 35 countries), percent }\end{array}$ & 0.6 & 1.2 & 1.2 & $0.3{ }^{\text {b) }}$ \\
\hline $\begin{array}{l}\text { Notes: }{ }^{\text {a) }} \text { adjusted such that private household plus corporate balances sum up to private sector } \\
\text { balance, b) relative to } 21 \text { countries } \\
\text { Source: European Commission (2012a), author's calculations }\end{array}$
\end{tabular}

In the period before the Great Recession, France, Italy and Portugal can neither be considered to have been debt-led consumption boom economies nor export-led mercantilist economies. Growth was rather domestic demand-led. The same characteristics hold for the EU12 as a whole. Although France and Italy saw significant increases in net wealth-income ratios and in residential property prices, whereas Portugal did not (BIS, 2010; Girouard et al., 2007; Hein, 2012b), financial balances of private households remained positive in the three countries. The corporate sector had negative balances in these countries and together with negative public sector balances this meant considerable current account deficits in Portugal, whereas in France and Italy the current accounts were roughly balanced on average over the period considered here. Growth in these countries was driven by domestic demand and the growth contribution of net exports remained close to zero in the cases of Italy and Portugal, or took small negative values in the case of France. Net exports remained positive for France and Italy, but were highly negative for Portugal. Considering nominal unit labor cost growth and inflation reveals that even France, although being perfectly in line with the ECB inflation target of "below, but close to 2 percent", lost price competitiveness relative to most of the export-led mercantilist economies, in particular relative to Germany. In Italy and Portugal unit labor costs growth and inflation were well above the ECB target and the average rate of inflation of the EU-12 suggesting severe problems of price competitiveness in these countries, as indicated by the increases in the real effective exchange rates. Real GDP growth in the domestic demand-led economies remained low in Italy and Portugal, but France managed to perform better than Germany and grew at a similar rate as Belgium. 


\section{EURO CRISES AND DEFLATIONARY STAGNATION POLICIES}

When the Great Recession hit the European economies in 2008/09, the three types of capitalism under financialization outlined in the previous section were affected and real GDP declined in all of the countries in our data set, in some of them considerably (Figure 3). In the course of the crisis government deficits increased in order to stabilise the private economic and financial sectors and government gross debt-GDP ratios jumped up (Figures 4 and 5).

\section{Figure 3}

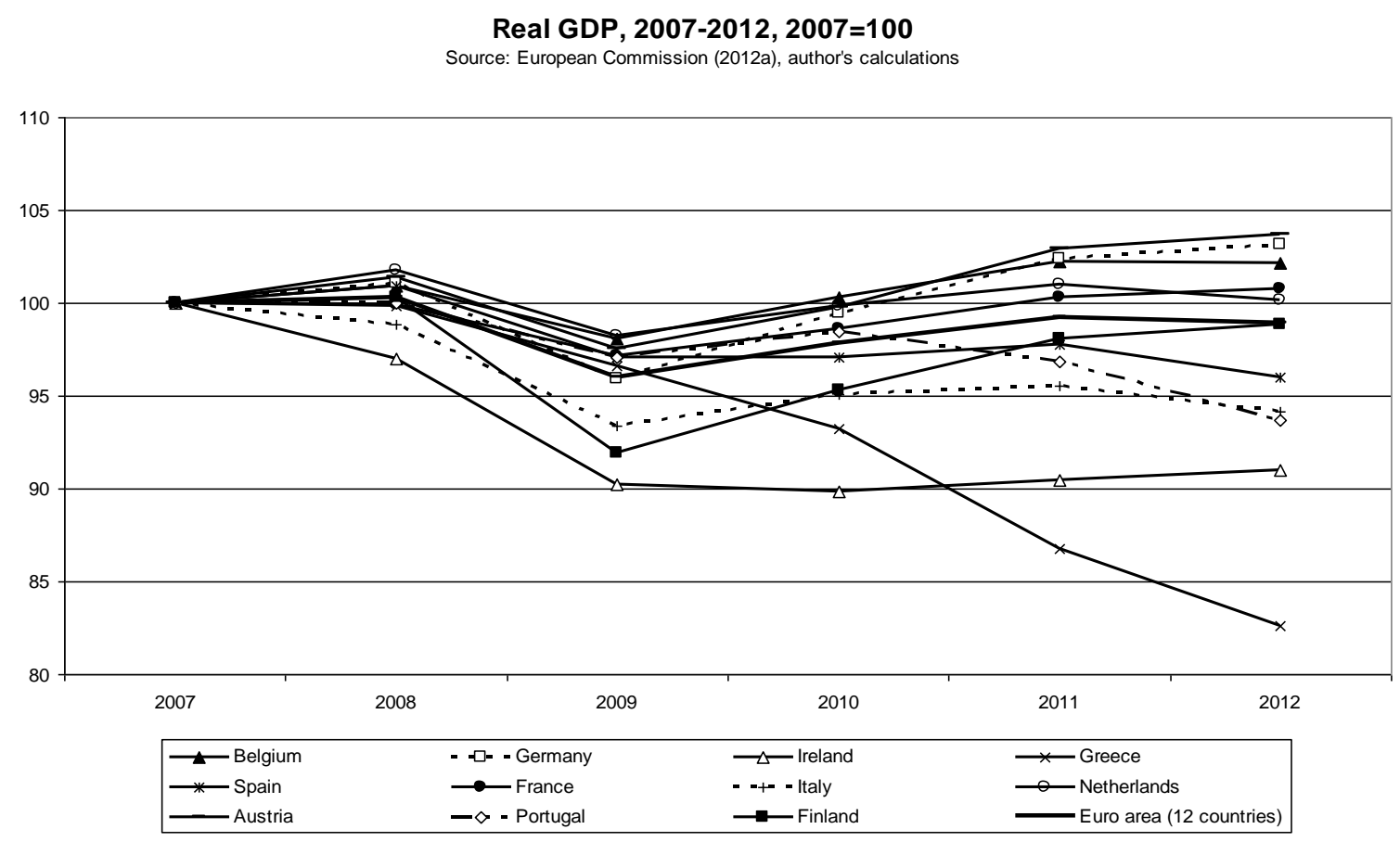

Note: Values for 2012 are based on European Commission forecasts. 


\section{Figure 4}

General government financial balance relative to GDP, in per cent 1995-2012 Source: European Commission (2012a), author's calculations

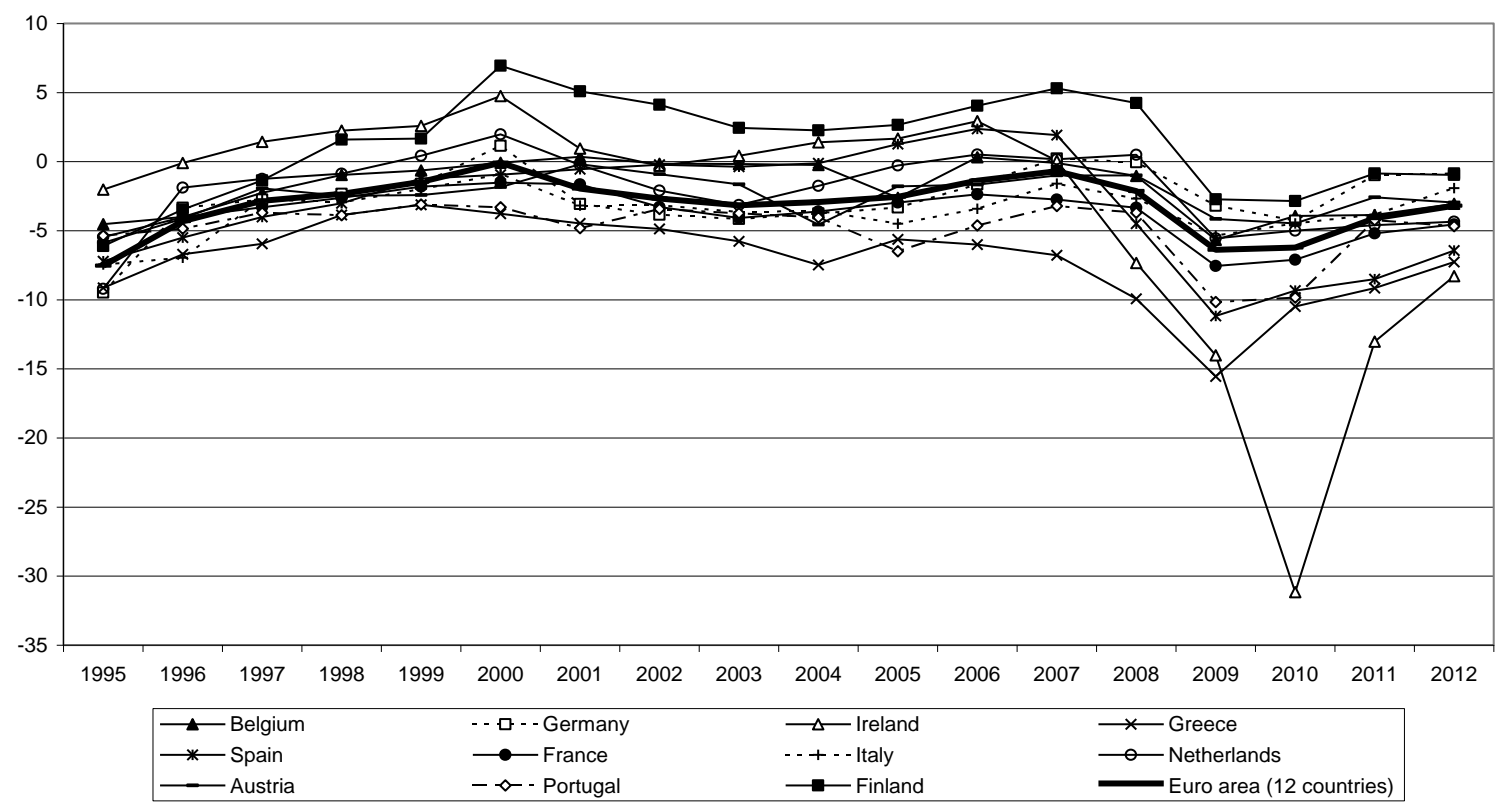

Note: Values for 2012 are based on European Commission forecasts.

\section{Figure 5}

General government gross consolidated debt relative to GDP, in percent, 1995-2012 Source: European Commission (2012a), author's calculations

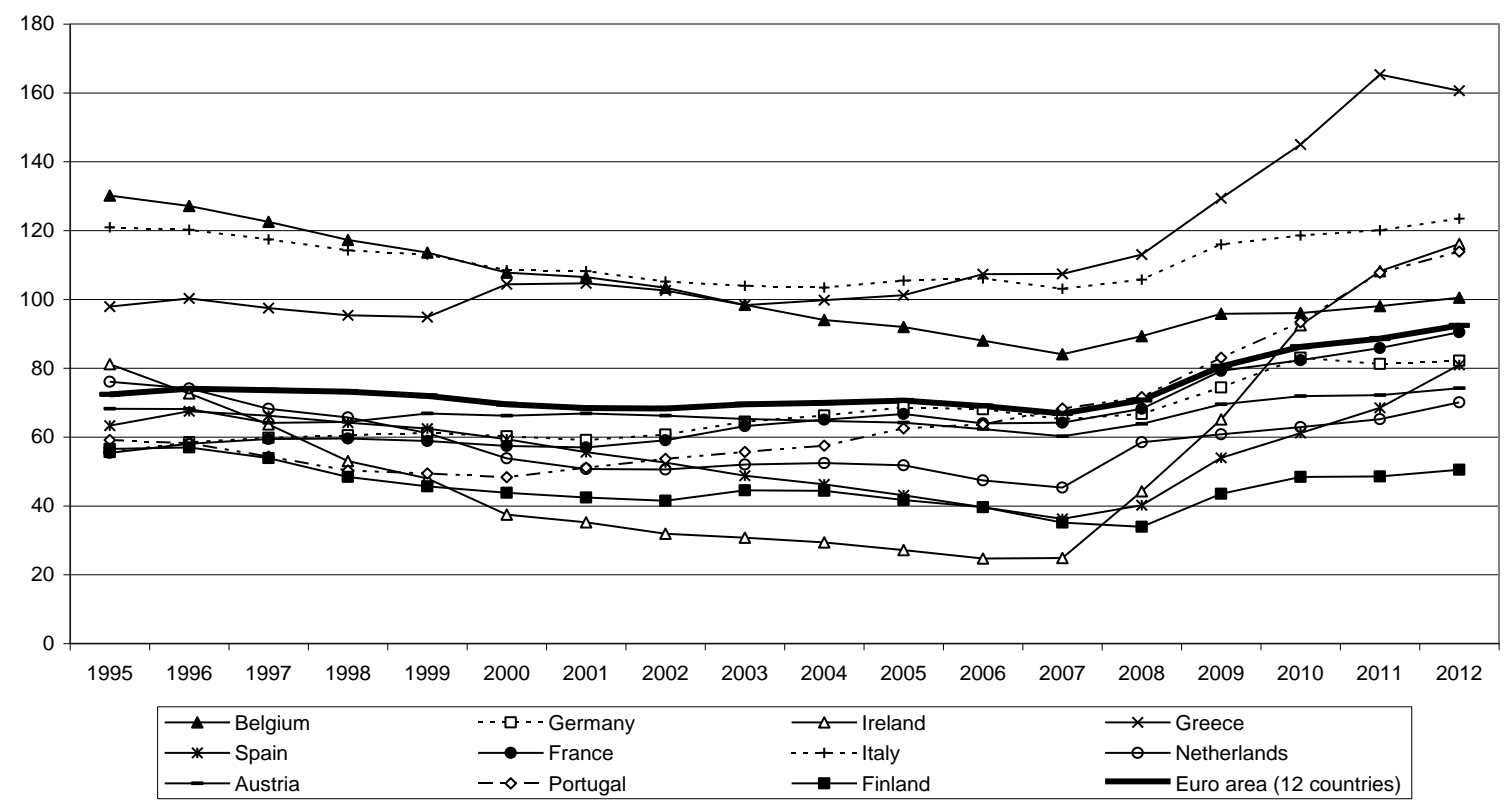

Note: Values for 2012 are based on European Commission forecasts.

These empirical developments seem to be one of the reasons why the current euro-crisis is considered as a crisis of government deficits and debt by many observers - above all by the 
dominant economic policy makers in Germany, the European Commission and the European Council. ${ }^{6}$ Superficially, this view seems to have some merits: Since the start of the global financial crisis in 2007 the spreads of government bond yields of Euro area member countries relative to the benchmark German bonds increased, most notably for Greece, Ireland and Portugal (Figure 6). This development continued, especially for Ireland and Greece and particularly so in mid-2009. In spring 2010, the development escalated dramatically again in the Greek case. Emergency measures had to be taken in order to prevent a Greek government default. However, the relief provided by the rescue package for Greece ( $€ 110$ Billion) by the Euro area countries and the IMF, and by the European Financial Stability Mechanism (EFSM) and the European Financial Stability Facility (EFSF) set up subsequently to prevent further problems for other governments, proved to be very short-lived. ${ }^{7}$ In October 2010, spreads for Irish government bonds increased dramatically again so that in November of the same year, the Irish government finally decided to request assistance by the EFSM, the EFSF and the IMF ( $€$ 85 Billion). In spring 2011, the Portuguese government had to do the same (€ 78 Billion). And in the course of 2011, the Greek government debt problem worsened again, such that in late 2011 a more than 50 percent voluntary loss of private holdings of Greek government debt and an increase and extension of the rescue package were agreed, using the EFSF as a financing vehicle.

\footnotetext{
${ }^{6}$ See for example the argument of the German Federal Ministry of Finance (2011) in the German Stability Programme submitted to the European Commission and the European Council (2011a) in its proposal for the Euro Plus Pact.

${ }^{7}$ See European Commission (2012b) for information on the Greek Loan Facility and European Commission (2012c) for information on the European Financial Stability Mechanism (EFSM), the European Financial Stability Facility (EFSF) and the rescue packages provided for Ireland and Portugal. On the EFSF operations see also EFSF (2012a).
} 


\section{Figure 6}

10-year government bond yields, January 2007 - June 2012

Source: European Central Bank (2012a)

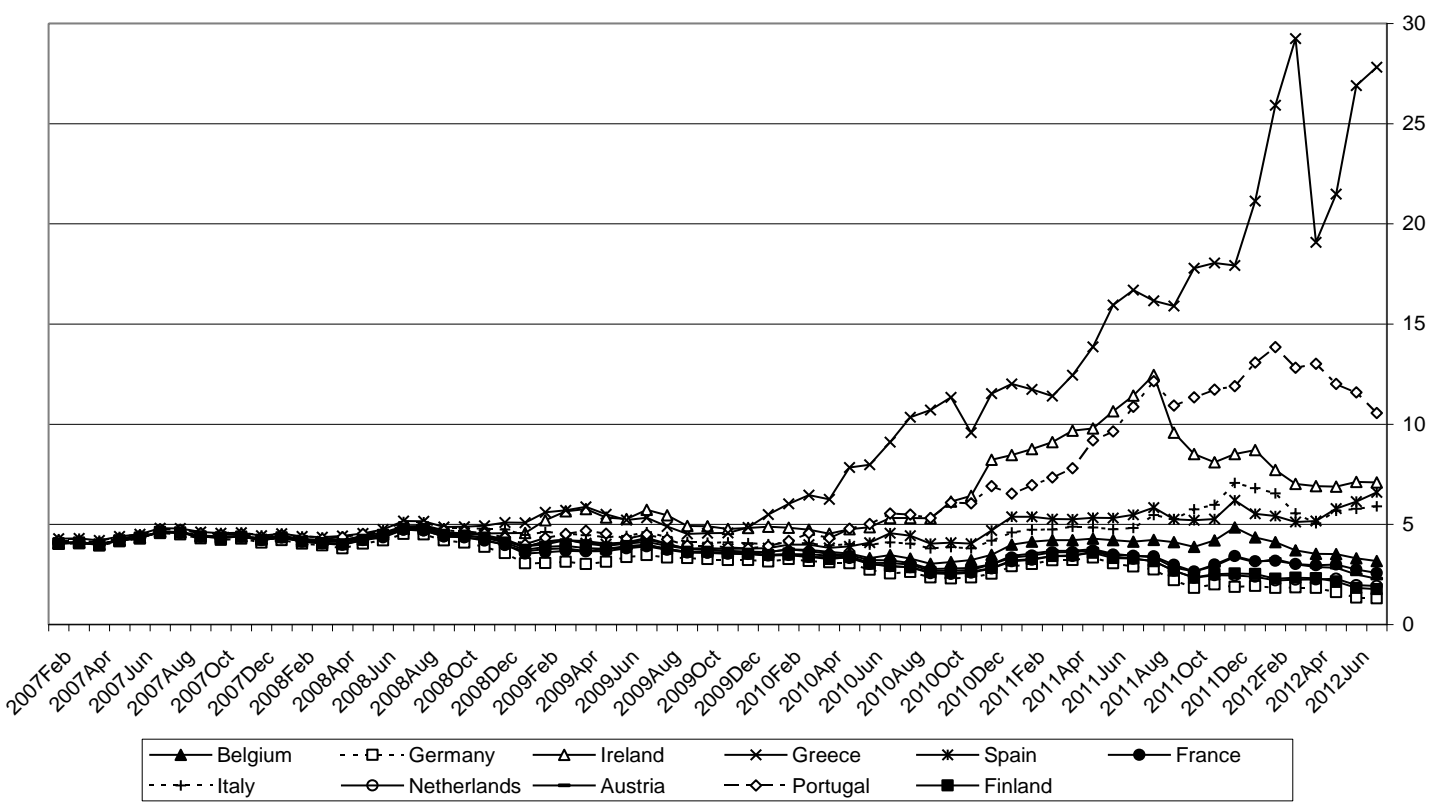

Although mainstream economics and economic policy debates see the high and rising government debts as the main reason for the crisis and consider the failure of the Stability and Growth Pact (SGP) to contain government deficits and debt to be the most important problem to be tackled in the Euro area, some important emergency measures have been taken to stabilise financial markets and prevent government defaults. These are, first, the introduction of the European Financial Stability Facility (EFSF) as well as the European Financial Stabilisation Mechanism (EFSM), as we have already mentioned above, and finally the European Stability Mechanism (ESM). Second, the stabilization tools of the EFSF and ESM have been gradually extended, such that the EFSF and then the ESM have been (will be) allowed to finance recapitalization of financial institutions through loans to governments and to intervene into secondary government bond markets under certain conditions. ${ }^{8}$ Third, and maybe more importantly, the interventions of the ECB into secondary government bonds markets, buying

\footnotetext{
${ }^{8}$ See for example the agreements of the meeting of the heads of state or government of the Euro area and EU institutions in July 2011 (Council of the EU, 2011b). The Euro area summit in June 2012 has even proposed the direct recapitalisation of banks by the ESM, provided that a European banking supervision is establishes: "When an effective single supervisory mechanism is established, involving the ECB, for banks in the euro area the ESM could, following a regular decision, have the possibility to recapitalize banks directly." (European Council, 2012b, p.1)
} 
government debt of those countries which are in trouble, have so far prevented a collapse of these markets and have provided some relief for the countries under attack. ${ }^{9}$

But these measures have been far from solving the major institutional deficiencies, which are the lack of an explicit guarantee of public debt of member countries by the ECB and the lack of a stable and sustainable internal financing mechanism of current account imbalances. For example, the meeting of the European Council (2011b) in December 2011 did not even consider the proposal of Eurobonds (or Stability Bonds) put forward by the European Commission (2011) which could have been a first step towards the remedy of the problems. And the ECB has been criticized again and again for its interventions into the secondary government bond market, in particular by major German economists, central bankers and policy makers.

Furthermore, the rescue measures for the member countries in trouble have been combined with the requirements of restrictive fiscal and wage policies as conditions to get access to the rescue packages mentioned above, with a tighter SGP, a new "Euro Plus Pact", and a new "Fiscal Compact". ${ }^{10}$ For example, in March 2011, the European Council (2011a, p. 2) "endorsed the priorities for fiscal consolidation and structural reform. It underscored the need to give priority to restoring sound budgets and fiscal sustainability, reducing unemployment through labor market reforms and making new efforts to enhance growth". In particular, the European Council (2011a, p. 2) requires reductions of the structural budget deficits of "well above 0.5 percent of GDP" for 2012 in most countries, in order to restore "confidence". ${ }^{11}$ The Euro Plus Pact agreed upon at that meeting is mainly targeted at improving competitiveness by means of monitoring wage setting, in particular in the public sector, at labor market reforms increasing "flexicurity", promoting life-long learning and reducing taxes on low-paid labor, and at improving sustainability of public finances by means of extending effective retirement ages, reducing early retirement and implementing fiscal rules (i.e., "debt brakes") into national legislation.

\footnotetext{
${ }^{9}$ For information on these interventions see ECB (2011b).

${ }^{10}$ See the agreements of the meeting of the Economic and Financial Affairs Council (ECOFIN) on 15 March 2011 (Council of the EU, 2011a), the conclusions of the meeting of the European Council (2011a) on 24/25 March 2011, the statement by the heads of state or government of the Euro area and EU institutions on 21 July 2011 (Council of the EU, 2011b), and state by the Euro area heads of state and governments on 9 December 2011 (European Council, 2011b).

${ }^{11}$ See also the agreement of the ECOFIN regarding the reform of the SGP and the surveillances of economic policies (Council of the EU, 2011a).
} 
This approach was underlined by the agreement of the Euro area heads of state and governments in December 2011 on the Fiscal Compact (European Council, 2011b). ${ }^{12}$ This Fiscal Compact reinforces the target of balanced or in surplus government budgets (i.e., structural deficits should not exceed 0.5 percent of GDP). This target is to be introduced into the constitutions of the contracting member countries. Furthermore, deviations from this target are to trigger automatic correction mechanisms. Such automatism, including sanctions imposed by the European Commission, shall also be applied if a country breaches the 3 percent of GDP limit for its government deficit, unless a qualified majority of the Euro area member states is opposed. Furthermore, it has been agreed to reduce government debt exceeding the 60 percent of GDP threshold by $1 / 20$ per year, irrespective of the macroeconomic conditions.

Far from addressing the two major institutional problems of the Euro area pointed out above, the focus of European policy makers on government deficits and debt as a cause of the crisis also does not meet the facts, if we take a closer look at the pre-crisis period since 1999 and remind ourselves of a simple accounting identity:

\section{Public sector financial balance}

+ Private sector financial balance

+ Foreign sector financial balance

$$
=0
$$

Out of the so-called crisis ridden GIPS countries, the dynamic debt-led consumption boom economies of Ireland (Figure 7) and Spain (Figure 8) had seen considerable surpluses in the public sector financial balances (see also Table 2a) and government gross debt-GDP ratios well below the 60 percent threshold of the Treaty and the SGP (Figure 5). It was the private sector which had huge deficits which were balanced by large external sector surpluses and hence current account deficits against the rest of the world. When the crisis hit, the private sector balances quickly turned into surplus and governments stabilising the economy had to accept dramatic increases in government deficits. Therefore, the government deficits which occurred in the course of the crisis turn out to be a consequence of unsustainable private and external sector balances before the crisis, given the two institutional deficiencies of the Euro area in the first place.

\footnotetext{
${ }^{12}$ The Treaty on Stability, Coordination and Governance in the Economic and Monetary Union on the Fiscal Compact is an inter-governmental contract of $25 \mathrm{EU}$ member states, because the UK and the Czech Republic refrained from joining this treaty (European Council, 2012a).
} 
Figure 7

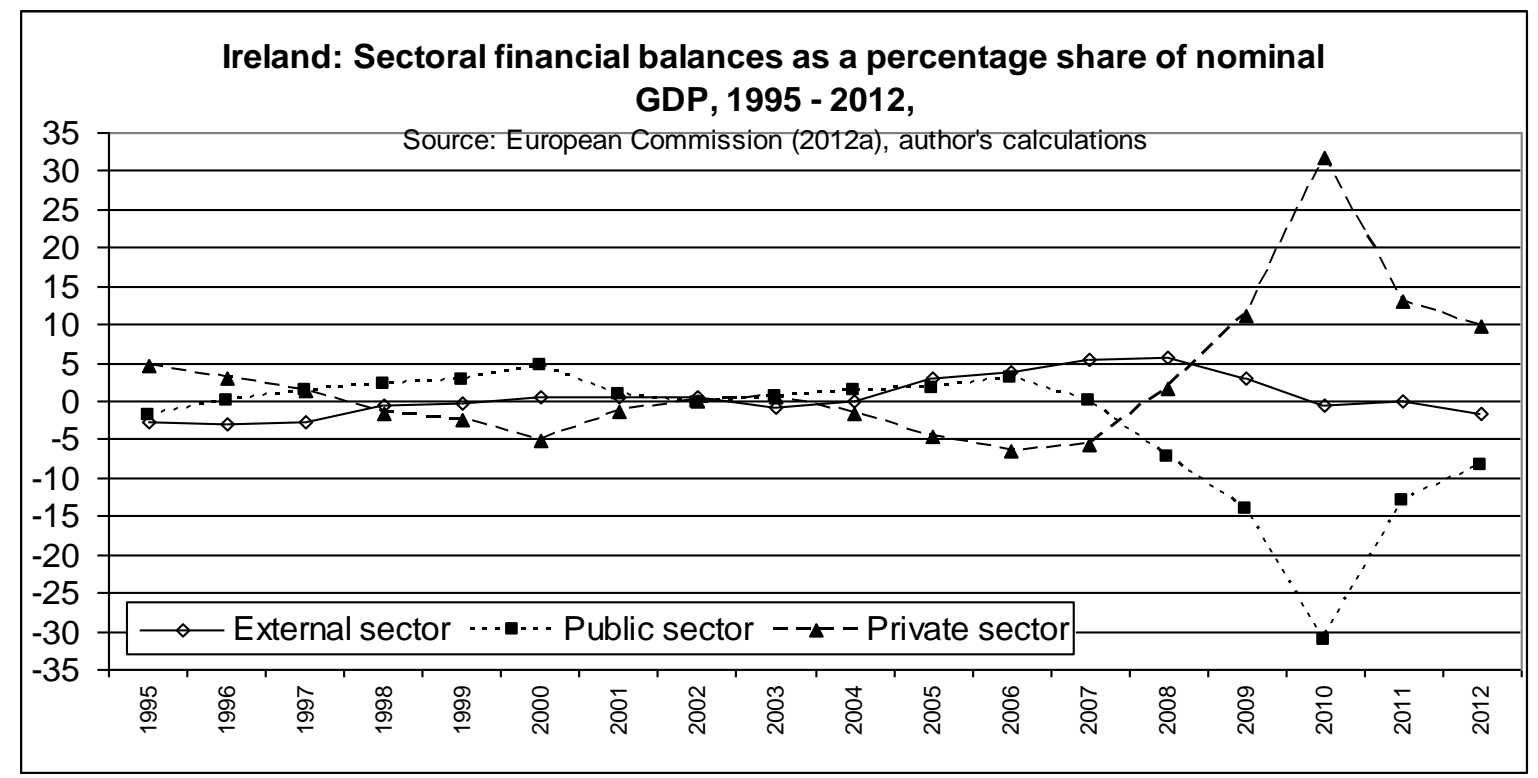

Note: Values for 2012 are based on European Commission forecasts.

\section{Figure 8}

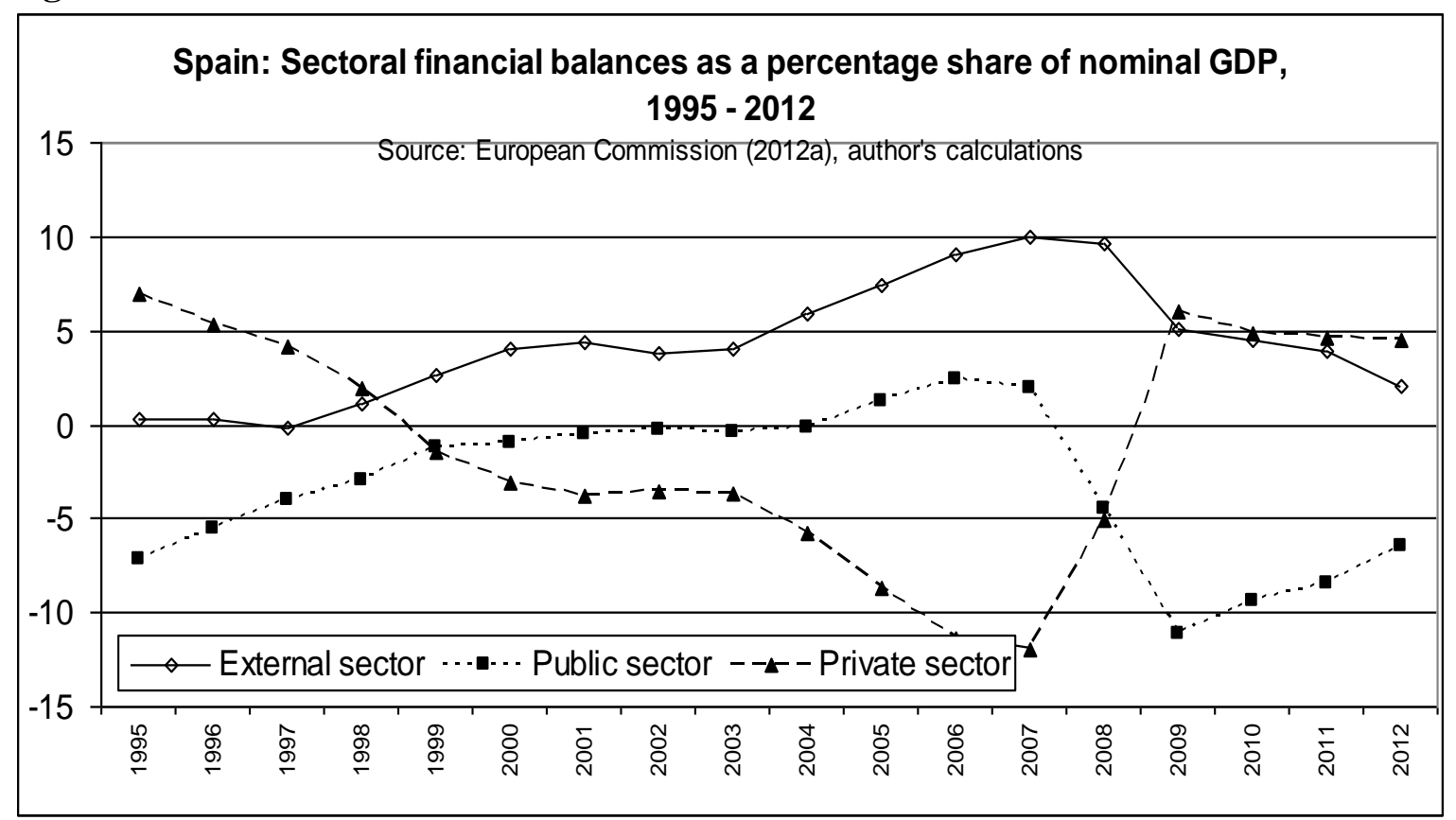

Note: Values for 2012 are based on European Commission forecasts. 
For the two other EU-12 economies currently included in the rescue packages, Greece (Figure 9), a debt-led consumption boom type, and Portugal (Figure 10), a domestic demand-led type of economy before the crisis, both the private sector and the government sector continuously ran deficits after the introduction of the euro. Before the crisis, those deficits had to be financed by capital inflows and hence considerable current account deficits. In the course of the financial and economic crises, in both countries the government stepped in to prevent the economy from collapsing when the private sector reduced deficits or began to run surpluses again, leading to rising public deficits.

\section{Figure 9}

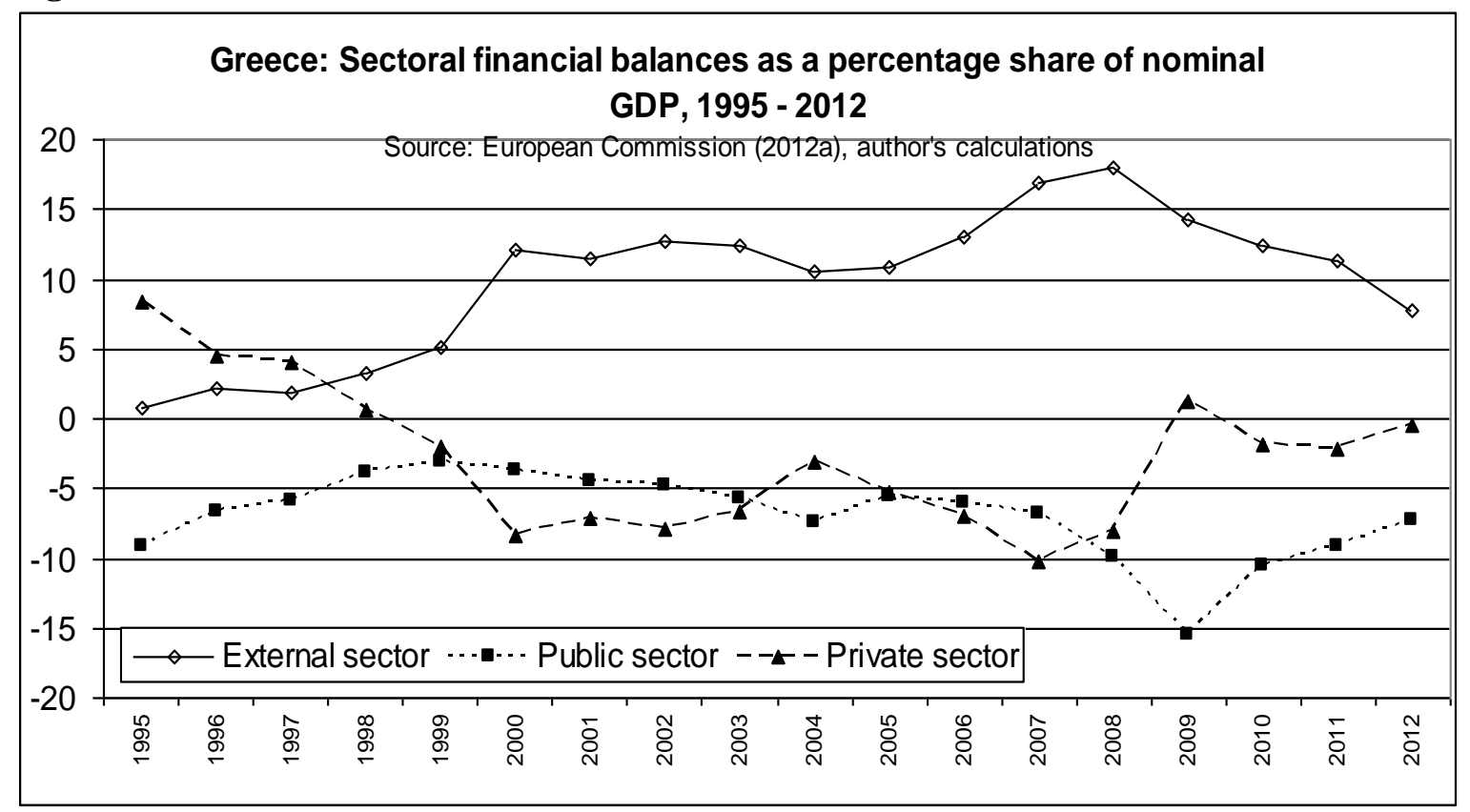

Note: Values for 2012 are based on European Commission forecasts. 
Figure 10

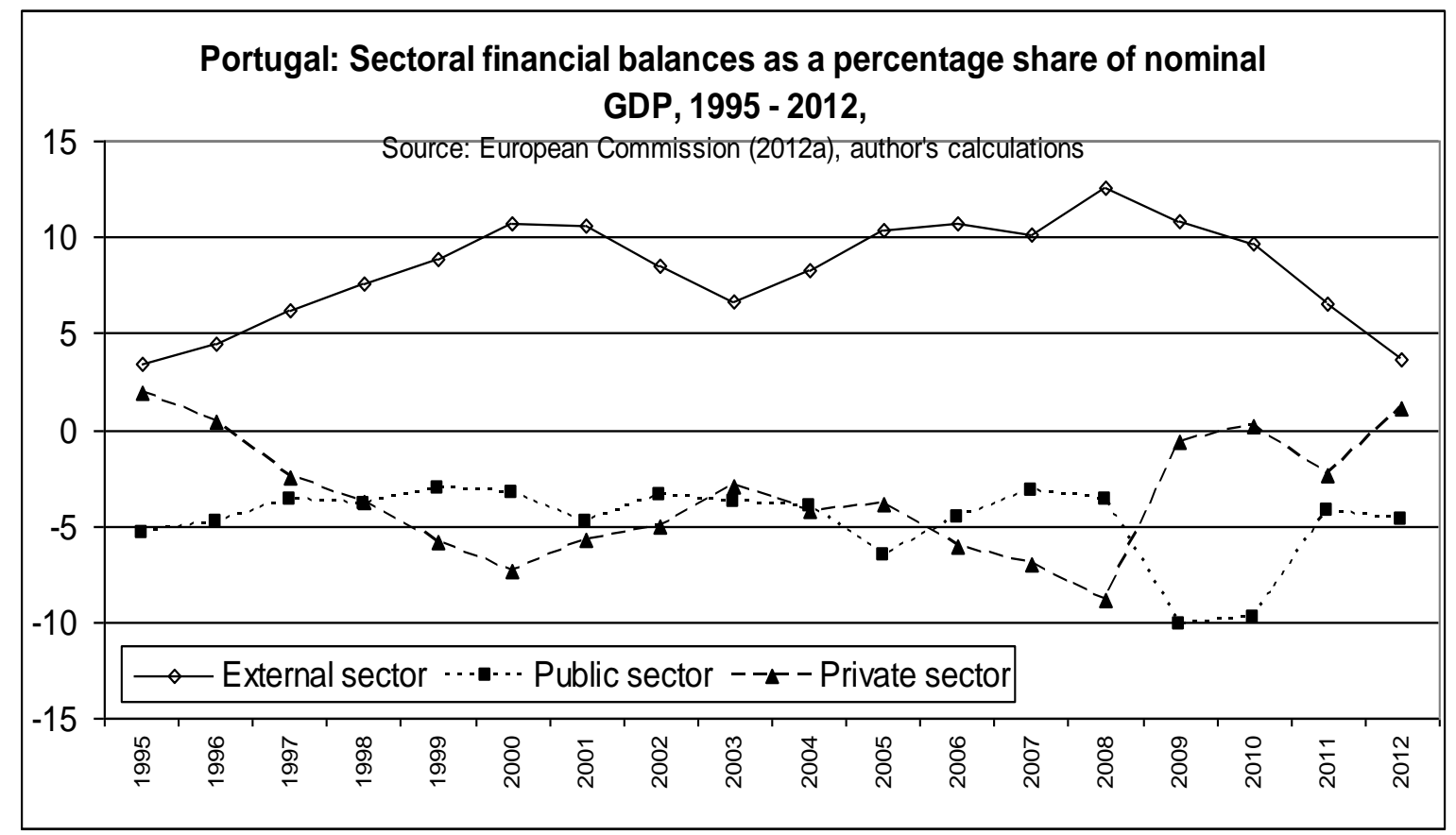

Note: Values for 2012 are based on European Commission forecasts.

Taking a broader perspective, under the given institutional architecture the current eurocrisis is rooted in private deficits and current account imbalances and was not caused by excessive public deficits. ${ }^{13}$ In the four countries outlined above, the private sector tended to spend more than its income. This was associated with government surpluses (Ireland, Spain) or amplified by government deficits (Portugal, Greece), which led to very high and rising current account deficits in the four countries. Since the current account of the Euro area as a whole, and also the EU-12 considered here, was roughly balanced in the period before the crisis, the counterparts to the current account deficit countries can be found within the Euro area or the EU-12, respectively. These are the export-led mercantilist countries of the Euro area identified in Section 2 (Table 2b), with Germany (Figure 11) as the largest Euro area country being the most important one. ${ }^{14}$

\footnotetext{
${ }^{13}$ For similar explanations see Uxo et al. (2011) and Stockhammer (2011).

${ }^{14}$ For a more detailed analysis and critique of the mercantilist macroeconomic policy strategy in Germany and its implications for the imbalances in the Euro area see Hein and Truger $(2007,2009,2010)$ and Cesaratto and Stirati (2010).
} 


\section{Figure 11}

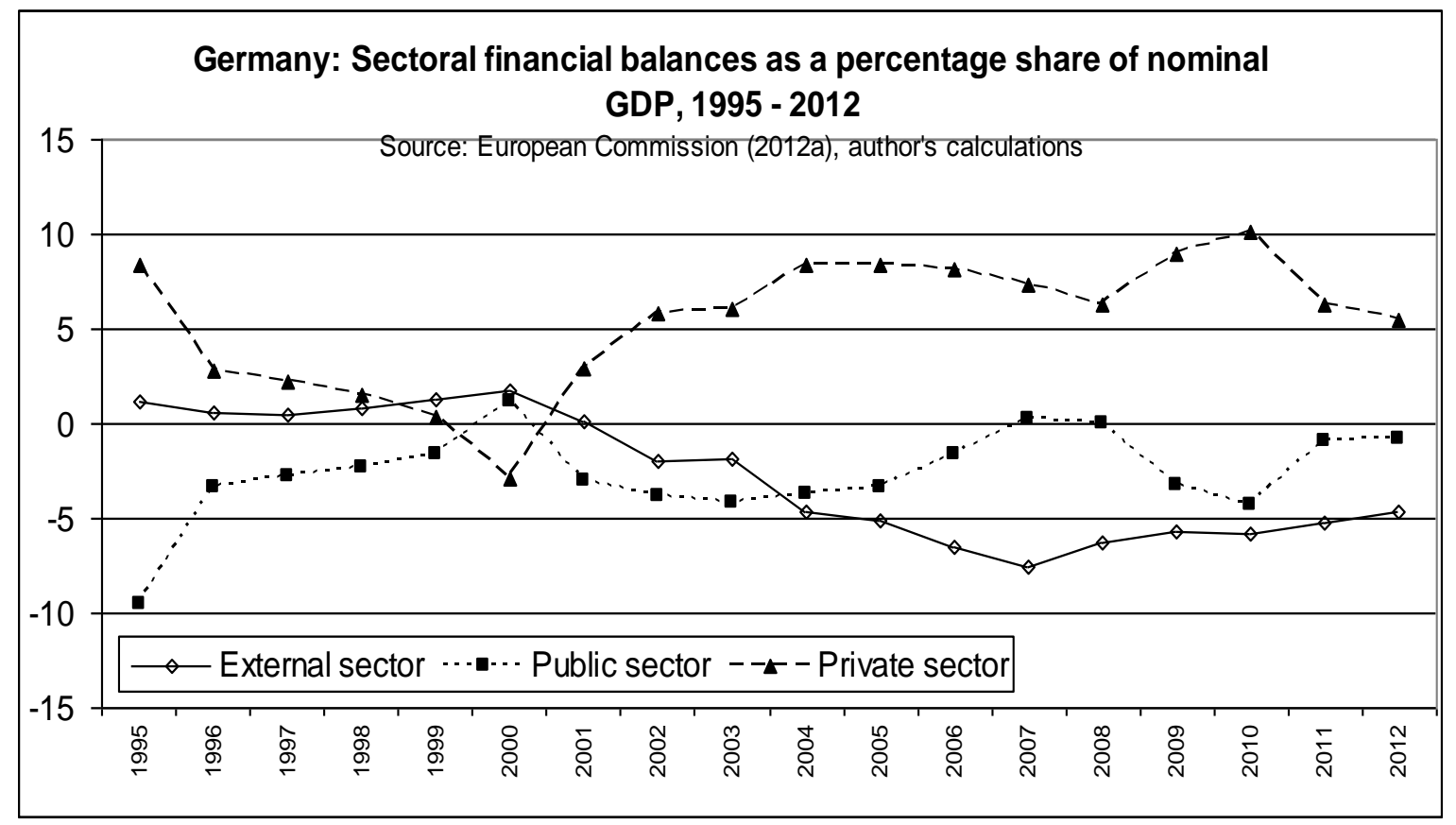

Note: Values for 2012 are based on European Commission forecasts.

Since the economic policy responses towards the crisis have neither addressed the deficiencies in economic policy architecture of the Euro area nor correctly identified the true causes of the crisis, given these deficiencies, it is not surprising that the outcomes of these policies have been disastrous so far. Until 2012 real GDP of the EU-12 has not yet recovered to its pre-crisis level in 2007 (Figure 3). Finland, Italy, Spain, Portugal, Ireland and in particular Greece are way below their respective pre-crisis levels. Out of this group, only Finland and Ireland have seen a rising real GDP trend since 2010, whereas the other countries have faced almost continuously shrinking or stagnating real GDP since the start of the crisis. 
Table 3a

\begin{tabular}{|c|c|c|c|}
\hline \multicolumn{4}{|c|}{$\begin{array}{c}\text { Key macroeconomic variables for "debt-led consumption boom" economies, average } \\
\text { values, } 2008-2012^{\text {b) }}\end{array}$} \\
\hline & Greece & Ireland & Spain \\
\hline $\begin{array}{l}\text { Annual change in labor income share, as percentage of GDP at } \\
\text { current factor costs }\end{array}$ & -1.1 & -0.3 & -0.9 \\
\hline $\begin{array}{l}\text { Financial balances of external sector as a share of nominal GDP, } \\
\text { percent }\end{array}$ & 12.7 & 1.3 & 5.0 \\
\hline $\begin{array}{l}\text { Financial balances of public sector as share of nominal GDP, } \\
\text { percent }\end{array}$ & -10.5 & -14.8 & -8.0 \\
\hline $\begin{array}{l}\text { Financial balance of private sector as a share of nominal GDP, } \\
\text { percent }\end{array}$ & -2.3 & 13.5 & 3.0 \\
\hline $\begin{array}{l}\text { Financial balance of private household sector as a share of } \\
\text { nominal GDP, percent a) }\end{array}$ & -10.6 & 4.1 & 3.2 \\
\hline $\begin{array}{l}\text { Financial balance of the corporate sector as a share of nominal } \\
\text { GDP, percent }\end{array}$ & 8.3 & 9.4 & 0.3 \\
\hline Real GDP growth, percent & -3.7 & -1.8 & -0.8 \\
\hline $\begin{array}{l}\text { Growth contribution of domestic demand including stocks, } \\
\text { percentage points }\end{array}$ & -5.7 & -4.8 & -2.9 \\
\hline Growth contribution of private consumption, percentage points & -2.0 & -1.4 & -0.8 \\
\hline Growth contribution of public consumption, percentage points & -0.9 & -0.5 & 0.0 \\
\hline $\begin{array}{l}\text { Growth contribution of gross fixed capital formation, } \\
\text { percentage points }\end{array}$ & -2.4 & -2.9 & -2.1 \\
\hline $\begin{array}{l}\text { Growth contribution of the balance of goods and services, } \\
\text { percentage points }\end{array}$ & 2.1 & 3.1 & 2.1 \\
\hline $\begin{array}{l}\text { Net exports of goods and services as a share of nominal GDP, } \\
\text { percent }\end{array}$ & -9.5 & 17.7 & -1.8 \\
\hline Growth rate of nominal unit labor costs, percent & 0.3 & -1.6 & 0.0 \\
\hline Inflation (HCPI growth rate), percent & 2.6 & 0.5 & 2.2 \\
\hline $\begin{array}{l}\text { Growth rate of nominal effective exchange rates (relative to } 35 \\
\text { countries), percent }\end{array}$ & 0.3 & -0.1 & 0.0 \\
\hline $\begin{array}{l}\text { Growth rate of real effective exchange rates (relative to } 35 \\
\text { countries), percent }\end{array}$ & -1.8 & -3.6 & -2.1 \\
\hline
\end{tabular}


Table 3b

\begin{tabular}{|c|c|c|c|c|c|}
\hline \multicolumn{6}{|c|}{$\begin{array}{l}\text { Key macroeconomic variables for "export-led mercantilist" economies, average values, } \\
\qquad 2008-2012^{\text {b) }}\end{array}$} \\
\hline & Austria & Belgium & Finland & $\begin{array}{l}\text { Ger- } \\
\text { many }\end{array}$ & $\begin{array}{l}\text { Nether- } \\
\text { lands }\end{array}$ \\
\hline $\begin{array}{l}\text { Annual change in labor income share, as } \\
\text { percentage of GDP at current factor costs }\end{array}$ & 0.6 & 0.5 & 0.9 & 0.8 & 0.4 \\
\hline $\begin{array}{l}\text { Financial balances of external sector as a } \\
\text { share of nominal GDP, percent }\end{array}$ & -2.9 & -1.7 & -1.1 & -5.5 & -5.6 \\
\hline $\begin{array}{l}\text { Financial balances of public sector as share } \\
\text { of nominal GDP, percent }\end{array}$ & -3.0 & -3.5 & -0.6 & -1.9 & -3.8 \\
\hline $\begin{array}{l}\text { Financial balance of private sector as a } \\
\text { share of nominal GDP, percent }\end{array}$ & 6.0 & 5.2 & 1.7 & 7.4 & 9.5 \\
\hline $\begin{array}{l}\text { Financial balance of private household } \\
\text { sector as a share of nominal GDP, } \\
\text { percent a) }\end{array}$ & 4.2 & 4.0 & -2.3 & 5.7 & 0.7 \\
\hline $\begin{array}{l}\text { Financial balance of the corporate sector } \\
\text { as a share of nominal GDP, percent }\end{array}$ & 1.8 & 1.2 & 4.0 & 1.7 & 8.7 \\
\hline Real GDP growth, percent & 0.9 & 0.5 & -0.1 & 0.7 & 0.0 \\
\hline $\begin{array}{l}\text { Growth contribution of domestic demand } \\
\text { including stocks, percentage points }\end{array}$ & 0.8 & 0.6 & 0.6 & 0.8 & -0.2 \\
\hline $\begin{array}{l}\text { Growth contribution of private } \\
\text { consumption, percentage points }\end{array}$ & 0.5 & 0.6 & 0.8 & 0.4 & -0.3 \\
\hline $\begin{array}{l}\text { Growth contribution of public } \\
\text { consumption, percentage points }\end{array}$ & 0.3 & 0.2 & 0.2 & 0.4 & 0.4 \\
\hline $\begin{array}{l}\text { Growth contribution of gross fixed } \\
\text { capital formation, percentage points }\end{array}$ & 0.0 & -0.1 & -0.4 & 0.1 & -0.3 \\
\hline $\begin{array}{l}\text { Growth contribution of the balance of } \\
\text { goods and services, percentage points }\end{array}$ & 0.2 & -0.1 & -0.7 & -0.2 & 0.3 \\
\hline $\begin{array}{l}\text { Net exports of goods and services as a } \\
\text { share of nominal GDP, percent }\end{array}$ & 4.2 & 1.8 & 1.0 & 5.3 & 7.9 \\
\hline $\begin{array}{l}\text { Growth rate of nominal unit labor costs, } \\
\text { percent }\end{array}$ & 2.5 & 2.8 & 3.5 & 2.2 & 2.1 \\
\hline Inflation (HCPI growth rate), percent $^{\text {a) }}$ & 2.3 & 2.6 & 2.7 & 1.8 & 1.8 \\
\hline $\begin{array}{l}\text { Growth rate of nominal effective exchange } \\
\text { rates (relative to } 35 \text { countries), percent }\end{array}$ & -0.2 & -0.1 & -0.4 & -0.3 & 0.0 \\
\hline $\begin{array}{l}\text { Growth rate of real effective exchange } \\
\text { rates (relative to } 35 \text { countries), percent }\end{array}$ & 0.1 & 0.6 & 1.0 & -0.2 & 0.0 \\
\hline $\begin{array}{l}\text { Note: }{ }^{\text {a) }} \text { adjusted such that private household ple } \\
\text { values for } 2012 \text { are based on forecasts by the E} \\
\text { Source: European Commission (2012a), author }\end{array}$ & - & blor & $\mathrm{m}$ up to $\mathrm{p}$ & 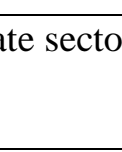 & ince, ${ }^{\text {b) }}$ \\
\hline
\end{tabular}


Because of the crisis in the former debt-led consumption boom economies, Greece, Ireland and Spain, and thanks to austerity policies and a falling labor income share, the growth contributions of domestic demand and its components have been negative, on average over the period 2008 until 2012, in these countries (Table 3a). The growth contributions of net exports of goods and services have turned positive, net export-GDP ratios have improved, but have remained considerably negative in Greece and slightly so in Spain. The major reason for improved net exports has been shrinking domestic demand and hence imports, on the one hand, and improved price competitiveness, measured by the rate of change in the real exchange rate, based on stagnating (Greece, Spain) or shrinking (Ireland) nominal unit labor costs, on the other hand.

Turning to the domestic demand-led economies, we find that Portugal basically displays a similar pattern as Greece, Ireland and Spain in the period 2008-12 (Table 3c), whereas Italy has not seen an improvement in price competitiveness based on stagnating or falling nominal unit labor costs. Unit labor cost growth and inflation in 2008-12 have remained at the levels of the pre-crisis period 1999-07, and price competitiveness has not improved. Small positive growth contributions of net exports in Italy have therefore been due to shrinking import demand caused by negative growth contributions of domestic demand. However, net exports as share of GDP have deteriorated, as has the current account (i.e., the financial balance of the external sector increased significantly). France is the only domestic-demand led economy, which managed to catch up to its pre-crisis real GDP in the course of the recovery (Figure 3). Under the conditions of an increase in the wage share, as a stabilizer of aggregate demand in a recession, the recovery has been based on domestic demand only, and average growth contributions of net exports have remained zero. Although average inflation has been in line with the ECB inflation target and with average in inflation in the EU-12, and price competitiveness measured by the real effective exchange rate has not declined, the net exportGDP ratio has deteriorated and become negative, as has the current account, which means that the financial balance of the external sector has turned positive. ${ }^{15}$

\footnotetext{
${ }^{15}$ The reason for this may be more dynamic domestic demand relative to the trading partners, an increase in the income elasticity of imports, or a decline in the income elasticity of exports. In other words, either GDP growth has exceeded the French balance of payments (BoP) constrained growth rate (Thirlwall, 1979, 2002), or the latter has declined.
} 
Table 3c

\begin{tabular}{|c|c|c|c|c|}
\hline $\begin{array}{r}\text { Key macroeconomic variables for "domestic demand- } \\
-2012^{\text {b) }}\end{array}$ & ed"' econ & mies, a & erage valu & $\mathbf{s}, 2008$ \\
\hline & France & Italy & Portugal & EU-12 \\
\hline $\begin{array}{l}\text { Annual change in labor income share, as percentage of } \\
\text { GDP at current factor costs }\end{array}$ & 0.6 & 0.4 & -0.5 & 0.4 \\
\hline $\begin{array}{l}\text { Financial balances of external sector as a share of } \\
\text { nominal GDP, percent }\end{array}$ & 2.3 & 2.7 & 8.7 & 0.0 \\
\hline $\begin{array}{l}\text { Financial balances of public sector as share of nominal } \\
\text { GDP, percent }\end{array}$ & -5.5 & -3.7 & -6.5 & -4.4 \\
\hline $\begin{array}{l}\text { Financial balance of private sector as a share of nominal } \\
\text { GDP, percent }\end{array}$ & 3.3 & 0.9 & -2.1 & 4.5 \\
\hline $\begin{array}{l}\text { Financial balance of private household sector as a } \\
\text { share of nominal GDP, percent a) }\end{array}$ & 4.3 & 2.2 & 2.5 & $\ldots$ \\
\hline $\begin{array}{l}\text { Financial balance of the corporate sector as a share of } \\
\text { nominal GDP, percent }\end{array}$ & -0.9 & -1.3 & -4.6 & $\ldots$ \\
\hline Real GDP growth, percent & 0.2 & -1.2 & -1.3 & -0.2 \\
\hline $\begin{array}{l}\text { Growth contribution of domestic demand including } \\
\text { stocks, percentage points }\end{array}$ & 0.2 & -1.5 & -3.0 & -0.6 \\
\hline $\begin{array}{l}\text { Growth contribution of private consumption, } \\
\text { percentage points }\end{array}$ & 0.3 & -0.4 & -1.2 & 0.0 \\
\hline $\begin{array}{l}\text { Growth contribution of public consumption, } \\
\text { percentage points }\end{array}$ & 0.3 & 0.0 & 0.0 & 0.2 \\
\hline $\begin{array}{l}\text { Growth contribution of gross fixed capital formation, } \\
\text { percentage points }\end{array}$ & -0.3 & -0.8 & -1.4 & -0.6 \\
\hline $\begin{array}{l}\text { Growth contribution of the balance of goods and } \\
\text { services, percentage points }\end{array}$ & 0.0 & 0.3 & 1.7 & 0.4 \\
\hline $\begin{array}{l}\text { Net exports of goods and services as a share of nominal } \\
\text { GDP, percent }\end{array}$ & -2.4 & -1.0 & -5.8 & 1.4 \\
\hline Growth rate of nominal unit labor costs, percent & 2.2 & 2.3 & 0.2 & 1.9 \\
\hline Inflation (HCPI growth rate), percent & 1.9 & 2.4 & 1.9 & 2.0 \\
\hline $\begin{array}{l}\text { Growth rate of nominal effective exchange rates } \\
\text { (relative to } 35 \text { countries), percent }\end{array}$ & -0.3 & -0.3 & -0.1 & $-0.5^{c)}$ \\
\hline $\begin{array}{l}\text { Growth rate of real effective exchange rates (relative to } \\
35 \text { countries), percent }\end{array}$ & 0.0 & 0.1 & -1.5 & $-0.6^{c)}$ \\
\hline
\end{tabular}

Most of the export-led mercantilist economies have recovered from the Great Recession and have reached their pre-crisis real GDP again in 2010 (Belgium) or 2011 (Austria, Germany, Netherlands) (Figure 3). Only Finland has not yet succeeded but its real GDP has shown a rising 
trend since 2010. With rising labor income shares, acting as a stabiliser of aggregate demand during a recession, economic recovery in this group of countries has mainly been driven by domestic demand, with the exception of the Netherlands (Table 3b). Only Austria and the Netherlands have accounted for positive growth contributions of net exports, whereas these have been slightly negative in Belgium and Germany, and more considerably so in Finland. Unit labor cost growth has increased relative to the pre-crisis period and has been higher than in the crisis countries. The export-led mercantilist countries have slightly lost ground with respect to price competitiveness, with the notable exceptions of Germany, which even improved price competitiveness measured by the real effective exchange rate, and the Netherlands. Net exportGDP ratios, however, have remained positive, with particularly high values in Austria, Germany and the Netherlands but less so in Belgium and Finland. The same results and pattern hold for the current account surpluses in these countries. The financial balances of the respective external sectors have remained negative, considerably so in the cases of Germany, the Netherlands and Austria, but less so for Belgium and Finland.

So far, deflationary stagnation policies since 2010 in the GIPS countries have improved their current account positions since the Great Recession, which means that the surpluses of the respective external sectors have declined significantly (Figures 7-10). In Ireland the financial balance of the external sector has turned negative already in 2010, and for 2012 it is expected to reduce to 2 percent for Spain, 3.6 percent for Portugal and 7.8 percent for Greece. This means that the 2012 value for Spain will be even smaller than the values for France (2.4 percent) and Italy (2.2 percent), which have shown a rising trend since the introduction of the euro. With the exception of the Netherlands, the current account surpluses, that is the deficits in the financial balances of the respective external sectors, of the export-led mercantilist economies have slightly declined after the Great Recession (Figure 2, and Figure 11 for Germany as an example). In Finland the external sector has even shown a surplus of around 0.4 percent of GDP since 2011. However, the deficits of the respective external sectors in the other countries will remain considerable in 2012. In Austria the financial balance of the external sector will be at 1.9 percent of GDP, in Belgium at -1.5 percent, in Germany at -4.7 percent and in the Netherlands at -8.0 percent. This means that after three years of deflationary stagnation policies remarkable current account imbalances within the Euro area persist (Figure 2). Furthermore, deflationary stagnation policies so far have failed to stop the rising trend of government gross 
debt-GDP ratios after the crisis in all the countries in our data set (Figure 5), ${ }^{16}$ although government deficit-GDP ratios have been considerably reduced (Figure 4). The divergence in the development of government deficit- and gross debt-GDP ratios is partly due to the fact that the government deficit is a net value, whereas government debt is taken as a gross value, and partly to the accounting procedure of Eurostat with respect to government interventions related to the support of financial institutions in the course of the crisis. ${ }^{17}$ With increasing government gross debt-GDP ratios it is, therefore, not surprising that the spreads of government bond yields have not converged at all during the period of deflationary stagnation policies (Figure 6). Whereas Irish government bond yields have started to decline in July 2011 and Portuguese yields in January 2012, there is no such tendency for Greek yields, and Spanish and Italian yields have shown a tendency to rise since spring 2012. Therefore, in June 2012 Spain had to ask the Euro group for EFSF assistance of up to $€ 100$ billion for recapitalising its banking sector and breaking the link between the troubled banking sectors and government debt yields (EFSF, 2012b; European Council, 2012b).

Summing up, deflationary stagnation policies in the Euro area since 2010 have meant massive real GDP losses (and related increases in unemployment and poverty not discussed here) in the former debt-led consumption boom economies as well as in Portugal and Italy, due to a policy induced collapse of domestic demand; some improvement in price competitiveness of these countries due to deflationary wage developments, with the exception of Italy; some improvements in the current accounts, however, with considerable current account imbalances persisting in the Euro area as a whole; reductions in government deficit-GDP ratios but continuously rising trends in government gross debt-GDP ratios for all the core Euro area countries considered here; persistent differentials in government bond yields; the risk of a further recession for the Euro area as a whole - and an increasing risk of a final collapse of the euro as a currency.

\section{ALTERNATIVES TO DEFLATIONARY STAGNATION POLICIES}

\footnotetext{
${ }^{16}$ Whether the European Commission (2012a) forecast for Greece in 2012 which expects a fall in the government gross debt-GDP ratio will come true remains to be seen.

${ }^{17}$ See European Commission (2012d) for a detailed outline of the impacts of the interventions related to the support of the financial institutions on government deficits and government liabilities in Eurostat accounting.
} 
Getting out of the euro-crisis requires, on the one hand, addressing the long-run developments of finance-dominated capitalism which have caused the crisis of this type of capitalism (i.e., the inefficient regulation of financial markets, the increased inequality in income distribution, and the imbalances in the current accounts at the global and the European level). On the other hand, the European Union and the Euro area will have to overcome the specific institutional and economic policy failures which have made the financial and economic crises a euro-crisis. ${ }^{18}$

In Hein and Truger $(2011,2012)$ and Hein (2012) we have proposed a "Keynesian New Deal at the Global and the European Level" in order to tackle the roots of the crisis of financedominated capitalism. This policy package should include, first, the re-regulation of the financial sector in order to prevent future financial excesses and financial crises, second, the reorientation of macroeconomic policies towards stimulating and stabilising domestic demand, in particular in the current account surplus countries, and third, the reconstruction of international macroeconomic policy coordination and a new world financial order, in order to rebalance the world and the regional economies.

In what follows we apply this concept to the Euro area and take into account the required remedies of the deficiencies and malfunctions of the European economic policy architecture.

We base our arguments on the Post-Keynesian approach to macroeconomics and macroeconomic policies as developed in Hein and Stockhammer (2010) as a potential alternative to the now discredited New Consensus macroeconomics (NCM), on which much of the existing economic policy framework in the Euro area is built. ${ }^{19}$ The major aims of the reorientation of economic policies in the Euro area are to overcome the present economic and financial crisis, to improve the growth rate of the Euro area as a whole, and to avoid major imbalances in economic development across the Euro area member countries.

First, in order to overcome the present euro-crisis the ECB should not only act as a lender-of-last-resort for the banking system, it should also guarantee public debt of the Euro area member countries in a convincing way, allowing these countries to issue debt in their "own currency". This would immediately reduce the pressure imposed by "financial markets" on those countries presently in crisis and would provide the conditions for a long-run oriented solution to

\footnotetext{
${ }^{18}$ On the "design faults" of the European Monetary and Economic Union see also more extensively Arestis and Sawyer (2011), however, without establishing any relationship of the euro-crisis with the crisis of financedominated capitalism.

${ }^{19}$ For the NCM see Goodfriend and King (1997), Clarida et al. (1999) and Woodford (2003), and for detailed critiques of the NCM and its application in economic policy making in the EU, see Arestis $(2009,2011 \mathrm{a}, 2011 \mathrm{~b})$, Arestis and Sawyer (2004a), and Hein and Stockhammer (2010).
} 
the current account imbalances within the Euro area. The ECB could simply announce that it will intervene into secondary government bond markets as soon as the rate of interest on government bonds exceeds the long-run nominal rate of growth of the respective country. ${ }^{20}$ Furthermore, the ECB should modify its monetary policy strategy and should take into account the long-run distribution, employment and growth effects of its policies, and pursue a monetary policy targeting low real interest rates, below productivity growth in the Euro area as a whole. This should be conducive to real investment and growth. Finally, the ECB ought to focus on financial market stability. Instead of the blunt instrument of the interest rate it should introduce those instruments which are appropriate to contain bubbles in specific asset markets in specific countries or regions (i.e., credit controls or asset-based reserve requirements (Palley, 2010)).

Second, the SGP at the European level has to be abandoned and needs to be replaced by a means of coordination of national fiscal policies at the Euro area level which allows for the short- and long-run stabilising role of fiscal policies. Hein and Truger (2007) have suggested the coordination of long-run expenditure paths for non-cyclical government spending (i.e., those components of spending which are under control of the government). Such expenditure paths could be geared towards stabilising aggregate demand in the Euro area at non-inflationary full employment levels, and automatic stabilisers plus discretionary counter-cyclical fiscal policies could be applied to fight demand shocks. In order to avoid current account imbalances within the Euro area, these expenditure paths would have to make sure of the following: On average over the cycle and the average tax rate in each member country given, as a first approximation, the government deficits in single countries (i.e., government spending (G) minus taxes (T)) would have to be roughly equal to the excess of private saving (S) over private investment (I) in the respective country, such that the current accounts are roughly balanced at a high level of aggregate demand and non-inflationary full employment $(\mathrm{S}-\mathrm{I}=\mathrm{G}-\mathrm{T})$, and GDP growth is close to the balance of payments constrained growth rate of the individual country. This means, of course, following the functional finance approach proposed by Lerner (1942) and more recently again by Arestis and Sawyer (2004b), and including balance of payments

\footnotetext{
${ }^{20}$ Of course, this suggestion goes well beyond different proposals for eurobonds of different types, which are focusing on joint guarantees for only parts of government debt of member countries (Brunnermeier et al., 2011; Delpla and von Weizsäcker, 2010; European Commission, 2011) or even combine this with fixed rules for government debt repayment (SVR, 2011). Palley's (2011) proposal of a European Public Finance Authority issuing joint debt of Euro area member countries which the ECB is then allowed to trade may be an alternative to our suggestion. But here is not the place and space to go into a deeper discussion.
} 
considerations into this approach, as will be specified further below. ${ }^{21}$ As long as the inflation constraint is respected, which can be relaxed by incomes policies as explained below, and as long as the ECB is ready to guarantee public debt of member countries and to keep interest rates low, public deficits and debt related to this fiscal policy approach are not a problem at all.

Third, the orientation of labor market and social policies towards deregulation and flexibilization, still dominating in the EU and the Euro area, will have to be abandoned in favour of re-organising labor markets, stabilising labor unions and employer associations, and adopting Euro area-wide minimum wage legislation. ${ }^{22}$ This could provide the institutional requirements for the effective implementation of stabilising nominal wage policies. Nominal wages should rise according to the sum of long-run average growth of labor productivity in the respective national economy plus the target rate of inflation for the Euro area as a whole. This would contribute to roughly equal inflation rates across the Euro area, and it would prevent mercantilist strategies based on nominal wage moderation. Furthermore, it would contribute to stabilising the wage share in national income.

Fourth, in order to overcome the present imbalances in economic development within the Euro area, member countries should aim at adjusting actual GDP growth rates and balance of payments constrained growth rates. For the current account surplus countries, this means that they should use expansive fiscal policies to increase domestic demand. For a transitional period, they should also increase their rates of inflation relative to the rates of inflation in the current account deficit countries, in order to rebalance price competitiveness among Euro area member countries. Nominal wage growth should therefore exceed the wage norm mentioned above (i.e., the sum of national productivity growth plus the Euro area inflation target) during the adjustment process. The major task for the current account deficit countries, with the exception of Ireland, ${ }^{23}$ will be to improve their balance of payments constrained growth rates. This means, on the one hand, to contribute to a reduction of the inflation differentials with respect to the surplus countries, by means of nominal wage growth below the sum of national productivity growth plus the inflation target. In order to prevent the risk of deflation in these countries during

\footnotetext{
${ }^{21}$ On the determinants of the balance of payments constrained growth rate see Thirlwall $(1979,2002)$ and on the application of this concept to the analysis of the imbalances within a currency area (i.e., the Euro area) see Hein et al. (2012) and Hein (2012, chapter 8).

${ }^{22}$ Of course, this does not imply the same minimum wage rate for the whole Euro area, but country-specific minimum wages, which, however, should be set according to some Euro area wide rule.

${ }^{23}$ In the case of Ireland, the current account deficit was not due to a deficit in external trade but rather a deficit in the flows of primary incomes.
} 
the process of adjustment, the Euro area inflation target should be increased above the rather ambitious present target of "below, but close to 2 percent" for the harmonized index of consumer prices (HICP). On the other hand, current account deficit countries have to increase the income elasticity of demand for their exports and to reduce the income elasticity of demand for imports by means of industrial, structural and regional policies; this means they have to improve their non-price competitiveness.

Fifth, even if the adjustment processes of actual and balance of payments constrained growth rates in each of the Euro area member countries is accepted as an economic policy goal, we would not expect complete adjustment in the short or medium run. Growth rates of member countries will differ due to productivity catch-up processes, and it is not very likely that the more rapidly growing catching up countries will have lower inflation, higher income elasticities of demand for their exports, and lower income elasticities of demand for imports than the slowly growing more advanced economies, so that actual growth differentials would be matched exactly by balance of payments constrained growth differentials. Therefore, current account surpluses and deficits will arise due to these differentials. Coordinating fiscal policies and government deficits at the Euro area level should therefore take tolerable current account deficits associated with catch-up processes into account in the short and medium run. As shown in Hein et al. (2012), ${ }^{24}$ in a currency union with a balanced current account with the rest of the world and therefore with a (close to) zero net foreign assets/liabilities position, there is no risk that the current account deficit member countries will face exploding net foreign liabilities-GDP ratios, provided that GDP growth in the deficit countries exceeds growth in the surplus countries. Sustainably higher growth than that of the surplus countries on Euro area average should therefore be the ultimate criterion for tolerable current account deficits in the coordination process of economic policies within the Euro area.

Sixth, since acceptable current account deficits within the Euro area will have to be financed by capital imports, appropriate financial regulations, avoiding excessive asset price inflation and credit bubbles, are key prerequisites for sustainable growth and for the stability of productivity growth catch-up processes as well as for the related current account deficits and net foreign liabilities position. Long-term capital flows as a means of finance of acceptable current account deficits are therefore most important. Long-term direct investment may be the most

\footnotetext{
${ }^{24}$ See also Hein (2012, chapter 8).
} 
stable and beneficial, but structural effects (and also the outflow of profits) have to be taken into account. If capital inflows are financed by credit, the focus should be on long-term credit. The European Investment Bank, together with the European Regional and Structural Funds and the government institutions of the recipient countries, should therefore be involved in directing capital flows into appropriate sectors and areas of the current account deficit countries which facilitate real catch-up processes and avoid bubbles in certain sectors (i.e., in housing or financial sectors).

\section{CONCLUSIONS}

In this paper we have viewed the euro-crisis as the latest episode of the crisis of financedominated capitalism. For eleven initial Euro area countries we have analysed major features of finance-dominated capitalism, specifically the fall in the labor income share and increasing inequality of income distribution as well as the rising imbalances of current accounts within the Euro area. Against this background we have then examined the euro-crisis and the economic policy reactions of European governments and institutions. Since these policy makers narrowly interpret the crisis as a sovereign debt crisis caused by irresponsible behaviour of some member country governments, their policy reactions and recommendations have focussed on constraining government deficits and debt by means of tighter rules and deflationary policies. We have shown that deflationary stagnation policies in the Euro area since 2010 have meant massive real GDP losses, in particular in the crisis countries, some improvement in price competitiveness and in the current accounts of these countries, however, with considerable current account imbalances persisting in the Euro area as a whole, reductions in government deficit-GDP ratios but continuously rising trends in government gross debt-GDP ratios for all the Euro area countries considered here, persistent differentials in government bond yields, the risk of a further recession for the Euro area as a whole - and an increasing threat of a final collapse of the euro as a currency. Therefore, we have finally outlined an alternative macroeconomic policy approach tackling the basic contradictions of finance-dominated capitalism and the deficiencies of European economic policy institutions and economic policy strategies. What is urgently required in order to prevent a worsening of the crisis in the Euro area is, first, a central bank which convincingly guarantees public debt of Euro area member countries and which contributes to improved Euro area growth by means of targeting low real 
interest rates. Second, fiscal policies along functional finance lines will have to be applied and coordinated across the Euro area, taking our criterion for long-run acceptable current account deficits (and surpluses) on board. Third, wage and incomes policies should contribute to nominal stabilisation and prevent mercantilist strategies and the related imbalances, as well as to stable income shares. Fourth, active industrial and regional policies will have to be applied in order to facilitate sustainable catch-up processes of the less developed countries and regions within the Euro area. 


\section{REFERENCES}

Arestis, P. 2009. "New Consensus Macroeconomics and Keynesian Critique." In E. Hein, T. Niechoj and E. Stockhammer (eds.), Macroeconomic Policies on Shaky Foundations. Whither Mainstream Economics? Marburg: Metropolis, pp. 165-185.

_. 2011a. "Keynesian Economics and the New Consensus in Macroeconomics." In E. Hein and E. Stockhammer (eds.), A Modern Guide to Keynesian Macroeconomics and Economic Policies. Cheltenham: Edward Elgar, pp. 88-112.

__ 2011b. "European Economic and Monetary Union policies from a Keynesian Perspective." In E. Hein and E. Stockhammer (eds.), A Modern Guide to Keynesian Macroeconomics and Economic Policies. Cheltenham: Edward Elgar, pp. 191-214.

Arestis, P. and Sawyer, M. 2004a. Re-examining Monetary and Fiscal Policy for the $21^{\text {st }}$ Century. Cheltenham: Edward Elgar.

_. 2004b. "On Fiscal Policy and Budget Deficits." Intervention. Journal of Economics, 1 (2), pp. 61-74.

_. 2011. "The Design Faults of the Economic and Monetary Union." Journal of Contemporary European Studies, 19 (1), pp. 21-32.

Bibow, J. 2008. "The International Monetary (Non-) Order and The 'Global Capital Flows Paradox'."In E. Hein, T. Niechoj, P. Spahn and A. Truger (eds.), Finance-led Capitalism? Macroeconomic Effects of Changes in the Financial Sector. Marburg: Metropolis, pp. 219-248.

BIS 2010. Bank for International Settlements. Property Price Statistics, http://www.bis.org/statistics/pp.htm.

Brunnermeier, M. et al. 2011. European Safe Bonds: ESBies, http://euro-nomics.com/wpcontent/uploads/2011/09/ESBiesWEBsept262011.pdf.

Cesaratto, S. and Stirati, A. 2010. "Germany and the European and Global Crises." International Journal of Political Economy, 39 (4), pp. 56-86.

Clarida, R., Gali, J. and Gertler, M. 1999. "The Science of Monetary Policy: a New Keynesian perspective." Journal of Economic Literature, 37, pp. 1661-1707.

Council of the EU 2011a. Council Reaches Agreement on Measures to Strengthen Economic Governance. Brussels, 7681/11, PRESSE 63, 15 March 2011. 
_. 2011b. Statement by the Heads of State or Government of the Euro Area and EU

Institutions, Brussels, 21 July 2011.

Delpla, J. and von Weizsäcker, J. 2010. “The Blue Bond Proposal”, Bruegel Policy Brief, 2010/3, Brussels: Bruegel.

ECB 2012a. Long Term Interest Rate Statistics, http://www.ecb.int/stats/money/long/html/index.en.html.

_.2012b.Weekly Financial Statements, http://www.ecb.int/press/pr/wfs/2012/html/index.en.html.

EFSF 2012a. European Financial Stability Facility: Lending operations, http://www.efsf.europa.eu/about/operations/index.htm.

_. 2012b. Master Financial Assistance Facility Agreement Between the European Financial Stability Facility, Kingdom of Spain as Beneficiary Member State, Fondo de Reestructuracion Ordenada Bancaria as Guarantor and the Bank of Spain, http://www.efsf.europa.eu/attachments/efsf_spain_ffa.pdf.

European Commission 2011. Green Paper on the Feasibility of Introducing Stability Bonds, Brussels, COM(2011) 818 final, 23 November 2011.

_.2012a. AMECO Database, Spring 2012,

http://ec.europa.eu/economy_finance/db_indicators/ameco/index_en.htm.

_. 2012a. The Greek Loan Facility,

http://ec.europa.eu/economy_finance/eu_borrower/greek_loan_facility/index_en.htm.

. 2012c. European Financial Stability Mechanism (EFSM),

http://ec.europa.eu/economy_finance/eu_borrower/efsm/index_en.htm.

_. 2012d. Eurostat Supplementary Table for the Financial Crisis, Background Note (April 2012),

http://epp.eurostat.ec.europa.eu/portal/page/portal/government_finance_statistics/documen ts/Background_note_fin_crisis_Apr_2012_final.pdf.

European Council 2011a. Conclusions, EUCO 10/11, 24/25 March 2011.

_. 2011b. Statement by the Euro Area Heads of State or Government, Brussels, 9 December 2011. .2012a Treaty on Stability, Coordination and Governance in the Economic and Monetary

Union, 2 March 2012, http://european-

council.europa.eu/media/639235/st00tscg26_en12.pdf. 


\section{. 2012b. Euro Area Summit Statement. Brussels, 29 June 2012.}

Fitoussi, J.-P. and Stiglitz, J. 2009. "The Ways Out Of The Crisis And The Building Of A More Cohesive World", OFCE Document de Travail, No. 2009-17, Paris: OFCE.

German Federal Ministry of Finance 2011. German Stability Programme 2011 Update. Berlin.

Girouard, N., Kennedy, M. and Andre, C. 2006. "Has The Rise In Debt Made Households More Vulnerable?" OECD Economics Working Paper, No. 5358 ECO/WKP(2006)63, Paris: OECD.

Goodbody Stockbrokers 2009. Irish Economic Commentary, 15 October 2009, Dublin: Goodbody Stockbrokers.

Goodfriend, M. and King, R.G. 1997. "The New Neoclassical Synthesis and The Role Of Monetary Policy." In B.S. Bernanke and J.J. Rotemberg (eds.), NBER Macroeconomics Annual: 1997, Cambridge, MA: MIT Press, pp. 231-283.

Hein, E. 2011a. "Redistribution, Global Imbalances and the Financial and Economic Crisis The Case For A Keynesian New Deal." International Journal of Labor Research, 3 (1), pp. 51-73.

_. 2011b. "Financialisation, Re-Distribution, and the Financial and Economic Crisis - A Kaleckian Perspective." In T. Niechoj, Ö. Onaran, E. Stockhammer, A. Truger and T. van Treeck (eds.), Stabilising an Unequal Economy? Public Debt, Financial Regulation, and Income Distribution. Marburg: Metropolis, pp. 35-62.

_. 2012a. The Macroeconomics of Finance-dominated Capitalism - and Its Crisis.

Cheltenham: Edward Elgar.

_ 2012b. "Financialisation, Re-Distribution and The Financial And Economic Crisis - A

European Perspective." In E. Febrero and O. de Juan (eds.), Post-Keynesian Views of the Great Crisis and its Remedies. Abingdon: Routledge, forthcoming.

Hein, E. and Mundt, M. 2012. "Financialisation and the Requirements and Potentials For WageLed Recovery - A Review Focussing on the G20." ILO Conditions of Work and Employment Series No. 37, forthcoming, Geneva: ILO.

Hein, E. and Stockhammer, E. 2012. "Macroeconomic Policy Mix, Employment and Inflation In A Post-Keynesian Alternative To The New Consensus Model." Review of Political Economy, 22, pp. 317-354.

Hein, E. and Truger, A. 2007. "Germany‘s Post-2000 Stagnation In The European Context - A Lesson In Macroeconomic Mismanagement." In P. Arestis, E. Hein and E. Le Heron 
(eds.), Aspects of Modern Monetary and Macroeconomic Policies. Basingstoke: Palgrave Macmillan, pp. 223-247.

. 2009. "How To Fight (Or Not To Fight) A Slowdown." Challenge. The Magazine of Economic Affairs, 52 (3), pp. 52-75.

. 2010. "Financial Crisis, Global Recession And Macroeconomic Policy Reactions - The

Case Of Germany." In S. Dullien, E. Hein, A. Truger and T. van Treeck (eds.), The World Economy in Crisis - The Return of Keynesianism? Marburg: Metropolis, pp. 191-220. . 2011. "Finance-dominated Capitalism In Crisis - The Case For A Keynesian New Deal At The European and The Global Level." In P. Arestis and M. Sawyer (eds.), New Economics as Mainstream Economics, International Papers in Political Economy. Basingstoke:

Palgrave Macmillan, pp. 190-230.

. 2012. "Finance-dominated Capitalism In Crisis - The Case For A Global Keynesian New Deal." Journal of Post Keynesian Economics, forthcoming.

Hein, E., Truger, A., and van Treeck, T. 2012. "The European Financial And Economic Crisis: Alternative Solutions From A (Post-)Keynesian Perspective." In P. Arestis and M. Sawyer (eds.), The Euro Crisis. International Papers in Political Economy. Basingstoke: Palgrave Macmillan, pp. 35-78.

Kalecki, M. 1971. Selected Essays on the Dynamics of Capitalist Economy, 1933-1970. Cambridge: Cambridge University Press.

Lerner, A. 1943. "Functional Finance And Federal Debt." Social Research, 10, pp. 38-51.

Meyer, L.H. 2001. "Inflation targets and inflation targeting." Federal Reserve Bank of St. Louis Review, 83 (6), pp. 1-13.

OECD 2008. Growing Unequal? Income Distribution and Poverty in OECD Countries. Paris: OECD.

. 2012. OECD.StatExtracts, http://stats.oecd.org/Index.aspx.

Palley, T. 2010. "Asset Price Bubbles and Counter-Cyclical Monetary Policy: Why Central Banks Have Been Wrong and What Should Be Done." Intervention. European Journal of Economics and Economic Policies, 7, pp. 91-107.

_ . 2011. "Monetary Union Stability: The Need for a Government Banker and the Case for a European Public Finance Authority." IMK Working Paper 2/2011, Düsseldorf:

Macroeconomic Policy Institute (IMK), Hans Boeckler Foundation. 
Stockhammer, E. 2010a. "Income Distribution, The Finance-Dominated Accumulation Regime, and The Present Crisis." In S. Dullien, E. Hein, A. Truger and T. van Treeck (eds.), The World Economy in Crisis - the Return of Keynesianism? Marburg: Metropolis, pp. 63-86. _. 2010b. "Neoliberalism, Income Distribution and The Causes Of The Crisis." Research on Money and Finance, Discussion Paper No. 19, London: Department of Economics, SOAS. . 2011. "Peripheral Europe's Debt and German Wages. The Role of Wage Policy in the Euro Area." Research on Money and Finance, Discussion Paper No. 29, London: Department of Economics, SOAS.

SVR 2011. Verantwortung für Europa übernehmen. Jahresgutachten 2011/12, Wiesbaden: Statistisches Bundesamt.

Thirlwall, A.P. 1979. "The Balance Of Payments Constraint As An Explanation Of International Growth Differences." Banca Nazionale del Lavoro Quarterly Review, 128, pp. 45-53.

_. 2002. The Nature of Economic Growth. Cheltenham: Edward Elgar.

UNCTAD 2009. The Global Economic Crisis. Systemic Failures and Multilateral Remedies. New York and Geneva: UNCTAD.

Uxo, J., Paul, J. and Febrero, E. 2011. "Current Account Imbalances In The Monetary Union And The Great Recession: Causes And Policies." Panoeconomicus, 5, pp. 571-592.

Van Treeck, T. 2009. "The Political Economy Debate On 'Financialisation' - A Macroeconomic Perspective." Review of International Political Economy, 16, pp. 907944.

Van Treeck, T., Hein, E. and Dünhaupt, P. 2007. "Finanzsystem und wirtschaftliche Entwicklung: neuere Tendenzen in den USA und in Deutschland." IMK Studies 5/2007, Duesseldorf: Macroeconomic Policy Institute (IMK) at Hans Boeckler Foundation. Wade, R. 2009. "From Global Imbalances To Global Reorganisations." Cambridge Journal of Economics, 33, pp. 539-562.

Woodford, M 2003. Interest and Prices: Foundations of a Theory of Monetary Policy Princeton. NJ: Princeton University Press. 